\title{
An investigation into sentiment-induced institutional trading behavior and asset pricing in the REIT market
}

Article

Accepted Version

Das, P. K., Freybote, J. and Marcato, G. (2015) An investigation into sentiment-induced institutional trading behavior and asset pricing in the REIT market. Journal of Real Estate Finance and Economics, 51 (2). pp. 160-189. ISSN 1573-045X doi: https://doi.org/10.1007/s11146-014-9490-z Available at https://centaur.reading.ac.uk/60285/

It is advisable to refer to the publisher's version if you intend to cite from the work. See Guidance on citing.

To link to this article DOI: http://dx.doi.org/10.1007/s11146-014-9490-z

Publisher: Springer

All outputs in CentAUR are protected by Intellectual Property Rights law, including copyright law. Copyright and IPR is retained by the creators or other copyright holders. Terms and conditions for use of this material are defined in the End User Agreement.

www.reading.ac.uk/centaur 
Central Archive at the University of Reading

Reading's research outputs online 


\title{
An Investigation into Sentiment-Induced Institutional Trading Behavior and Asset Pricing in the REIT Market
}

\author{
Prashant K. Das ${ }^{1}$ \\ Julia Freybote ${ }^{2}$ \\ Gianluca Marcato ${ }^{3}$
}

\begin{abstract}
Institutional investors such as pension funds or insurance companies commonly invest in the unsecuritized and securitized real estate market. We investigate how institutional investor sentiment in the commercial real estate market affects institutional trading behavior in the REIT market and subsequently asset pricing. In particular, we test two alternative theories flight to liquidity and style investing theory - to explain the sentiment-induced trading behavior of institutional investors in the REIT market for the pre-crisis (2002-2006), crisis (2007-2009) and post-crisis (2010-2012) period. We find that the applicability of either theory depends on economic conditions. In the pre-crisis period institutional investors switched capital in and out of REITs based on their sentiment in the private market (style investing). However, in the crisis period institutional investors switched capital from the illiquid private market to the more liquid REIT market (flight to liquidity). The flight to more liquid REITs continued into the post-crisis to a lesser extent and suggests that the financial crisis has changed institutional investment behavior. Our findings hold across different groups of REITs (e.g. high and low institutional ownership, $S \& P$ and non-S\&P REITs) and property types. We also find that institutional real estate investor sentiment introduces a non-fundamental component into REIT pricing.
\end{abstract}

Keywords: Institutional investor sentiment; flight to liquidity; style investing; asset pricing; real estate

${ }^{1}$ Ecole Hôtelière de Lausanne, Route de Cojonnex 18, 1000 Lausanne 25, Switzerland;

2 Center for Real Estate, School of Business Administration, Portland State University, 631 SW Harrison St, Portland, OR 97201, USA; freybote@pdx.edu, 503-725-3727 (phone), 503-725-5850 (fax); Corresponding Author

${ }^{3}$ Henley Business School, University of Reading, Greenlands, Henley-on-Thames, Oxfordshire RG9 $3 \mathrm{AU}, \mathrm{UK}$ 


\section{Introduction}

Over the last couple of decades a number of studies have shown that fundamentals are not sufficient to explain the comovement of asset returns (e.g. Barberis, Shleifer and Wurgler, 2005; Pindyck and Rotemberg, 1993, 1990; Shiller, 1989). Investor sentiment has been identified as an additional driver of comovement of assets that either form a category or are in the habitat of a particular investor type (Barberis, Schleifer and Wurgler, 2005). The majority of studies investigating sentiment-induced comovement focus on the stock market and neglect assets that are simultaneously traded in securitized and unsecuritized markets. However, particularly these assets represent a unique laboratory to understand the role of investor sentiment in the comovement of assets across and within asset categories, classes and markets.

Real estate represents an asset class for which a securitized and unsecuritized market coexist. Both markets are used by institutional investors to obtain exposure to the "real estate category" and provide data about transaction activity, returns and investor sentiment. Institutional real estate investors commonly invest in real estate via investments in commercial real estate and publicly traded real estate investment trusts (REITs; Dhar and Goetzmann, 2006; Clayton and MacKinnon, 2003a; Ciochetti et al., 2002). Exposure to the private real estate market provides institutional investors with an information advantage about fundamentals when they trade REITs, whose pricing is ultimately driven by underlying asset values (Graff and Young, 1997). However, it also makes them susceptible to irrational sentiment, which is recognized to be an important component of investor decision-making in the highly intransparent, informationally inefficient and segmented commercial real estate market (Gallimore and Gray, 2002). As a consequence, the following two questions arise: 
- How does institutional investor sentiment in the unsecuritized market affect institutional investor trading in the securitized market?

- How does institutional investor sentiment affect asset pricing in the securitized market?

The real estate laboratory offers a unique opportunity to assess the impact of sentiment in the unsecuritized market on institutional trading behavior and asset pricing decisions in the securitized market. In this study, we investigate this relationship over the period of 2002 to 2012 by testing the applicability of the style investing and flight to liquidity theory, which are two alternative sentiment-based theories of comovement (Baker and Wurgler, 2007; Barberis, Schleifer and Wurgler, 2005). In particular, we test the explanatory power of the two theories for different periods: pre-crisis (2002 to 2006), crisis (2007 to 2009) and post-crisis (2010 to 2012). These periods are motivated by the findings of Devos et al. (2013) who show that institutional investment preferences in REITs changed around the most recent financial crisis.

The style investing theory predicts a capital switching in and out of the "real estate category", which includes securitized real estate assets (e.g. REIT stocks) and unsecuritized real estate assets (e.g. commercial real estate), based on the sentiment of institutional investors in the underlying private market. The flight to liquidity theory predicts a sentiment-induced capital switching from illiquid unsecuritized investments to more liquid securitized assets due to perceived liquidity risk. Previous studies provide evidence for both, an institutional style investing in REITs (Ambrose, Lee and Peek, 2007; Graff and Young, 1997) as well as a flight to quality/liquidity within the REIT market (Devos et al., 2013) or capital switching between REIT and commercial real estate market (Lee, Lee and Chiang, 2008). 
The purpose of our study is to combine the extensive literatures on style investing, institutional herding behavior and flight to liquidity/quality to explain the effect of sentiment in the unsecurititized real estate market on institutional REIT trading behavior, and create a link between the findings of these earlier studies. We also analyze whether institutional investor sentiment in the unsecuritized market adds a component delinked from fundamentals into asset pricing in the securitized market in line with the investor sentiment literature (e.g. Baker and Wurgler, 2007; Barberis, Shleifer and Wurgler, 2005; Barberis and Shleifer, 2003; De Long et al. 1990, 1989) and institutional investor herding literature (e.g. Choi and Sias, 2009; Sias, 2004; Nofsinger and Sias, 1999).

We find evidence for the applicability of both theories, albeit at different points in time, characterized by different economic conditions. In the pre-crisis period from 2002 to 2006, the sentiment-driven REIT trading behavior of institutional investors is best explained by style investing suggesting that institutional investors switched capital in and out of the real estate category based on their unsecuritized market sentiment. However, during the financial crisis from 2007 to 2009, the flight to liquidity theory best explains institutional trading behavior in the securitized market (i.e. REITs), suggesting a sentiment-induced capital switching from the illiquid unsecuritized to the more liquid securitized market to adjust portfolio weights within the real estate category. The flight to liquidity theory also best explains the effect of private market sentiment on institutional trading in the REIT market in the post-crisis period from 2010 to 2012, which suggests that the financial crisis has changed institutional investment behavior. Our findings are in line with Devos et al. (2013), and complement this earlier study by providing evidence that an institutional flight to quality/liquidity does not only exist within the REIT market, but also between the unsecuritized and securitized real estate market. 
Our results hold for securities forming the habitat of institutional investors (i.e. REITs included in the S\&P500 index and with high institutional ownership), securities forming the habitat of individual investors (i.e. REITs not included in the S\&P index and with low institutional ownership) and across REITs with different property type specializations. Additionally, we find that the sentiment of institutional investors in the unsecuritized market affects asset pricing in the securitized market.

Our study contributes to the style investing, herding and flight to liquidity/quality literatures as follows. First, we provide empirical evidence that institutions not only style invest across different types of stocks, but also across the securitized and unsecuritized real estate market. We also show that investor sentiment in the informationally inefficient unsecuritized market affects institutional investment across the real estate category and asset pricing decisions in the securitized market. Thus, there appears to be a spillover of sentiment between markets within the same asset category. Second, we provide evidence that the flight to liquidity/quality theory is not only applicable to the stock market or stock \& bond market, but also to the unsecuritized and securitized real estate market. Last, our results suggest that the flight to liquidity and style investing theory are complements, depending on economic conditions.

Furthermore, our study contributes to the existing literature on investor sentiment in private and public real estate markets. With the exception of Ling, Naranjo and Scheick (2013), previous REIT investor sentiment studies focus on individual investors (Lin, Rahman and Yung, 2009; Chiang and Lee, 2009; Clayton and MacKinnon, 2003a; Barkham and Ward, 1999). Traditionally, institutional investors have been considered to behave rationally and trade on expectations about fundamentals (Anand, Chakravarty and Martell, 2005; Brown and Cliff, 2004; Barberis and Shleifer, 2003; De Long et al. 1990, 1989). However, previous studies on 
institutional herding and momentum trading in REIT and non-REIT stocks (e.g. Ro and Gallimore, 2013; Sias, 2004; Badrinath and Wahal, 2002; Nofsinger and Sias, 1999) suggest that institutional investment decisions may not be entirely based on rational expectations about the future. The focus on institutional investors is particularly relevant, as institutional ownership in REITs has been continuously increasing since the beginning of the new "REIT era" (Devos et al., 2013; Lee, Lee and Chiang, 2008; Clayton and MacKinnon, 2003b; Below, Stansell and Coffin, 2000; Graff and Young, 1997). Our study also complements previous studies such as Below, Stansell and Coffin (2000), who investigate fundamentals-based determinants of institutional demand in REIT stocks in line with traditional capital asset pricing theory, by analyzing behavioral determinants of institutional investor demand for REITs.

The remainder of the paper is structured as follows: The next section discusses our theoretical foundation presenting a literature review. We then describe the data and methodology used in our study. Finally, we present our main results for both institutional REIT trading and pricing, followed by our conclusion.

\section{Literature Review}

Alongside more traditional asset pricing theory, a growing stream of literature finds that underlying fundamentals are not sufficient to explain the excess comovement of different assets (Barberis, Shleifer and Wurgler, 2005; Pindyck and Rotemberg, 1993, 1990; Shiller, 1989). Sentiment-based theories such as the category (style investing) and habitat theory offer alternative and behavioral explanations for how investor sentiment affects the comovement of asset returns (Barberis, Shleifer and Wurgler, 2005). 
Barberis and Shleifer (2003) refer to a category or "style" to define a group of risky assets that investors treat homogeneously and hence do not consider competing in their demand function. After combining assets into broader classes, investors then make portfolio allocation decisions at the category level instead of the individual asset level ("style investing"). In particular, investors categorize assets into superordinate styles and allocate funds to these categories based on the category's past performance relative to other categories. If a category has a relatively superior performance to others, switchers withdraw funds from underperforming categories and invest them in this overperforming category. As a consequence, regardless of cash flows, which may be either highly (e.g. utilities stocks) or weakly correlated (e.g. closed end funds), assets within the same category tend to comove (Barberis and Shleifer, 2003).

Empirical evidence for the category theory (style investing) has been found, for example, in "Siamese twins" companies traded in different markets (Froot and Dabora, 1999), commodities (Pindyck and Rotemberg, 1990), stocks in the same index (Barberis, Shleifer and Wurgler, 2005; Chen and Bondt, 2004), companies of the same size but different lines of business (Pindyck and Rotemberg, 1993), Morningstar categories (Teo and Woo, 2004), stocks with similar prices (Green and Hwang, 2009), and stocks with other similar characteristics (Wahal and Yavuz, 2013; Baker and Wurgler, 2006). Investigating the comovement of two overlapping stock market categories (REITs and S\&P index stocks), Ambrose, Lee and Peek (2007) find that after certain REITs were added to S\&P indices, both "index" and "non-index" REITs comove with the S\&P index stocks. Furthermore, institutional investors in particular have been found to herd from and to styles, for example, with regard to stock portfolios of particular characteristics (e.g. growth stocks or market capitalization) and industries (Choi and Sias, 2009; Froot and Teo, 2008). 
A number of studies find that unsecuritized and securitized real estate returns comove (Pagliari, Scherer and Monopoli, 2005; Myer and Webb, 1993; Giliberto, 1990). Pagliari, Scherer and Monopoli (2005) argue that public and private real estate are interchangeable from a portfolio management perspective. This suggests the existence of a "real estate category", based on the real estate industry, in which investors style-invest in line with Choi and Sias (2009). Graff and Young (1997) present evidence that institutional investors herd in and out of REIT stocks, based on the performance of the underlying commercial real estate market. If institutional investors indeed style-invest in the real estate category, we expect a positive relationship between the sentiment of institutional investors in the private market and their trading behavior in the public market.

The flight to liquidity theory, which has evolved from the noise-trader or habitat theory, offers an alternative explanation for sentiment-induced REIT trading of institutional investors. According to this theory (Lee, Shleifer and Thaler, 1991; De Long et al., 1989, 1990), noise trading by individual investors increases the systematic risk of assets that are in the preferred habitat of individual investors, and exposes rational investors to an additional risk delinked from fundamentals that cannot be arbitraged away. For real estate, the noise-trader theory has been empirically supported by a number of studies on individual investor sentiment in REITs (Lin, Rahman and Yung, 2009; Chiang and Lee, 2009; Clayton and MacKinnon, 2003a; Barkham and Ward, 1999).

However, Baker and Wurgler (2007) argue that noise trading also results in a flight to quality within the stock market. For example, in times of high sentiment characterized by increased volatility due to higher noise trading (Yu and Yuan, 2011), some investors move away from small, high growth and more volatile stocks whose prices are often driven by irrational 
sentiment, towards safe, more "bond-like" stocks, whose prices are less likely to be affected by sentiment. Amihud, Mendelson and Wood (1990) suggest that the flight to quality should be interpreted as a flight to liquidity. A number of studies provide empirical support for the flight to quality/liquidity theory within and across asset markets such as the bond and stock market (Goyenko and Ukhov, 2009; Brunnermeier and Pedersen, 2009; Beber, Brandt and Kavajecz, 2008; Acharya and Pedersen, 2005; Vayanos, 2004; Ilmanen, 2003).

With regard to the REIT market, Devos et al. (2013) find that institutional investments depend on REIT performance and economic conditions. The financial crisis led to a flight to quality of institutional REIT investors towards lower risk REITs, which led to an increase in institutional ownership in older and larger REITs in the post-crisis period. These REITs have been traditionally the habitat of institutional investors (Below, Stansell and Coffin, 2000). During the crisis, institutional investors exhibited a preference for REITs with higher turnover. As stocks with high turnover can be considered more liquid (Baker and Stein, 2004), this finding suggests a flight to liquidity within the REIT market.

An important characteristic of institutional real estate investors is their high sensitivity to illiquidity risk in the unsecuritized real estate market (Dhar and Goetzmann, 2006) and hence their preference for more liquid securitized real estate assets (Ciochetti, Craft and Shilling, 2002). Liquidity is an important distinction between direct and indirect real estate investments (Pagliari, Scherer and Monopoli, 2005). Clayton and MacKinnon (2003a) find that the liquidity premium in REIT prices relative to net asset values is related to the liquidity of the underlying commercial real estate market. Additionally, institutional investors have also been found to consider unsecuritized and securitized real estate as substitutes and switch their investments (capital) between these two markets (Lee, Lee and Chiang, 2008). As a consequence, if 
institutional investors switch capital from the illiquid unsecuritized to the more liquid securitized real estate market (flight to liquidity), we expect a negative relationship between the sentiment of institutional investors in the private market and their trading behavior in the public market.

\section{Data Description}

\section{Institutional Investor Sentiment for Private Real Estate}

In the investor sentiment literature, sentiment is measured with either the closed end fund discount (CEFD), surveys or cash flow imbalances/trading activity. Previous studies on REIT investor sentiment predominantly employ the CEFD or discount to net asset value approach, which however, is inappropriate for our investigation for a number of reasons. The indirect CEFD measure does not allow us to isolate institutional investor sentiment and also has been found to proxy primarily for individual investor sentiment (De Long and Shleifer, 1992; Lee, Shleifer and Thaler, 1991). Findings about the appropriateness of the CEFD measure as investor sentiment proxy furthermore have been mixed in the finance literature (Gemmill and Thomas, 2002; Neal and Wheatley, 1998; Doukas and Milonas, 2004; Sias, Starks and Tinic 2001; Elton, Gruber and Busse 1998; Chen, Kan and Miller, 1993).

To measure the sentiment of institutional investors in the unsecuritized commercial real estate market, we follow Ling, Naranjo and Scheick (2013) and Clayton, Ling and Naranjo (2009) and employ a survey-based measure, which is based on data from the Real Estate Research Corporation (RERC) over the period of Q1/2002 to Q2/2012. The RERC surveys institutional investors such as pension funds, insurance companies or investment managers involved in the commercial real estate market on a quarterly basis. Respondents are asked to provide information such as expectations about yields, growth rates and investment conditions in all major commercial real estate market segments (office, industrial, retail, apartment and hotel). 
In particular, we focus on the rankings of current investment conditions for office, industrial, retail, apartment and hotel. Respondents are asked to rate the current investment conditions from "poor" (1) to "excellent" (10). These rankings are direct measures of investor sentiment in the unsecuritized real estate market as they represent the expectations of market participants for the future (Clayton, Ling and Naranjo, 2009). For office, industrial and retail, current investment conditions are reported for more than one segment (e.g. office CBD and office suburban). As a consequence, we use principal components analysis (oblimin rotation) to extract a common factor or score for each property type with more than one segment. In particular, we retain the eigenvector with the highest eigenvalue (principal component), which is able to explain the largest variance in the respective data. For diversified REITs, we use a common factor derived from the investment conditions for all property types as sentiment measure. Our approach follows Ling, Naranjo and Scheick (2013). We then match the respective RERC sentiment score to REITs based on property type, e.g. we use the RERC retail sentiment score for REITs specializing in retail.

\section{Institutional Investor Trading in REITs}

We measure institutional investor trading behavior in the REIT market as buy-sell imbalance (BSI) in line with Kumar and Lee (2006). This measure has also been used as a proxy for investor sentiment. In our analysis, we focus on publicly traded US equity REITs specializing in office, industrial, apartment, retail and hotel as well as diversified REITs. This focus stems from the availability of RERC sentiment measures for these property types. We also only include REITs traded on the NYSE in our sample, as institutional investors prefer firms listed at this exchange (Below, Stansell and Coffin, 2000). We define BSI as follows: 


$$
B S I_{t}=\frac{\left(B_{t} S_{t}\right)}{\left(B_{t}+S_{t}\right)}
$$

Where $B_{t}\left(S_{t}\right)$ is the quarterly long (short) position of institutional investors in a particular REIT. The BSI measure indicates whether institutional investors are net buyers $\left(\mathrm{BSI}_{t}>0\right)$ or net sellers $\left(\mathrm{BSI}_{\mathrm{t}}<0\right)$ of shares of a particular REIT. A BSI of $1(-1)$ for a particular REIT suggests that institutional investors only purchased (sold) this REIT's shares in a particular quarter. A BSI of less that 1 or more than -1 indicates that institutional investors varied in their investment and divestment in shares of a particular REIT, i.e. some investors purchased stocks while others sold them in the same quarter.

To calculate the institutional investor BSI, we obtain information about institutional trading of individual REITs from the Institutional (13f) Holdings database (s34) in Thomson Reuters for the period of Q1/2002 to Q2/2012. Institutional investors covered by this dataset are pension funds, banks, insurance companies, parent companies of mutual funds and other institutions such as endowment funds. For each quarter, we derive the aggregated net change in the holdings of a particular REIT by institutional investors $\left(B_{t}-S_{t}\right)$ and aggregated total institutional investor trading volume of that REIT (aggregated absolute net change; $B_{t}+S_{t}$ ).

One shortcoming of the Thomson Reuters $13 \mathrm{f}$ data for our investigation is that it combines institutions invested in the unsecuritized and securitized market (pension funds, banks, insurance companies) with institutions that do not directly invest in real estate (mutual funds), but heavily invest in REITs (Devos et al., 2013). To control for the REIT trading of mutual funds, we derive a mutual fund BSI based on Equation 1 and data from the Mutual Fund Holdings database (s12) in Thomson Reuters. While the Institutional (13f) Holdings database includes aggregated mutual fund trading at the parent company level, the Mutual Fund Holdings 
database includes disaggregated trading by individual mutual funds. As the BSI measures are based on aggregated trading activity, these differences are irrelevant to our empirical analysis.

\section{Liquidity Control Measures}

Clayton and MacKinnon (2003a) find that investor sentiment is important to REIT pricing even after accounting for REIT and private market liquidity. Additionally, an extensive body of literature provides evidence for the importance of liquidity to asset pricing in the stock market (Liu, 2006; Acharya and Pedersen, 2005; Pastor and Stambaugh, 2003; Amihud, 2002; Amihud and Mendelson, 1986). In our empirical analysis, we control for the liquidity of individual REIT stocks and REIT market by using the Amihud (2002) illiquidity measure as shown in Equation 2. We also employ a modified Amihud (2002) measure to control for private market illiquidity. This modified measure allows the computation of the Amihud (2002) measure for private real estate, where information on daily pricing at index level is not available:

$$
I L L I Q_{i y}=\frac{\left|R_{i y}\right|}{V O L_{i y}}
$$

Where ILLIQ is the illiquidity of a REIT stock or property type $i$ in period $y, R$ is the absolute return and $V O L$ the trading volume. To calculate the illiquidity measure for different commercial property markets from Q1/2002 to Q2/2012, we obtain the quarterly property type-specific NCREIF transaction based index (NTBI) total return (in absolute terms) and divide it by the dollar-denominated trading volume, defined as quarterly property type-specific aggregate sale price.

We calculate individual stock and market illiquidity measures for REITs traded by institutional investors over the period of Q1/2002 to Q2/2012 based on the Institutional (13f) Holdings database (s34) in Thomson Reuters. We obtain information about quarterly REIT 
returns and total trading volume from CRSP and derive the REIT-level illiquidity measure based on Equation 2. The REIT market illiquidity measure represents a value-weighted (by market capitalization) quarterly aggregate of the REIT-level illiquidity values. In our analysis of the impact of institutional real estate investor sentiment on REIT pricing, we control for REIT-level illiquidity by using the mean-adjusted Amihud (2002) measure. The mean adjustment addresses variation in average market illiquidity over time and is derived by dividing the illiquidity measure for an individual stock by the respective market illiquidity measure (Amihud, 2002).

\section{Other Control Variables}

Finally, to control for the impact of other fundamentals on institutional REIT trading behavior, we include economic and capital market fundamentals in our model. At the macro-economic level, we control for unemployment $(U N P)$ by including the average quarterly unemployment rate from the Bureau of Labor Statistics (BLS). This variable, which is negatively related to gross domestic product (GDP; Knotek, 2007), proxies for demand for space which in turn affects real estate prices (Brooks and Tsolacos, 1999). It has also been used as a proxy for the general state of the economy in previous studies (Bianchi and Guidolin, 2014; Fei et al., 2010). In our analysis, we substituted unemployment with GDP, and results were qualitatively similar. As a consequence, we only report our results with the unemployment control variable.

At capital market level, we control for debt capital market conditions by including the term structure (Clayton, Ling and Naranjo, 2009) and the default risk premium/credit spread. The term structure (TRM) is defined as the difference between the yields of the 10-year treasury bond and 3-month treasury bill (Clayton, Ling and Naranjo, 2009). The default risk premium (SPR) is defined as difference between yield of BAA rated corporate bond and 1yr treasury bond. To 
control for the general stock market, we also include the return on the S\&P500 composite index from CRSP $(S N P)$.

As the REIT industry matured and market capitalization increased, a number of REITs have been added to Standard \& Poor stock market indices such as the S\&P400, 500 or 600. These stocks represent the preferred habitat of institutional investors, as they are larger, older and less volatile. To control for systematic differences between REITs included in S\&P indices and those that are not, we introduce a binary variable coded 1 for quarters in which a REIT was included in an index (SPINDEX). Lastly, we control for the level of institutional ownership in a REIT. The effect of institutional real estate investor sentiment on trading behavior may be systematically different for stocks with different levels of institutional and individual investor ownership. As a consequence, we obtain the total institutional ownership as a percentage of shares outstanding from Thomson Reuters and include INSTOWN in our analysis. In our sample 241 observations have an institutional ownership greater than $100 \%$, which is a well-documented issue of this database (Glushkov, Moussawi and Palacios, 2009). We drop these observations from our sample.

An overview of our variables, their definitions, computations and data sources is provided in Table A1 in the Appendix. Our panel dataset covers 2,357 REIT quarters for 68 REITs over the period of Q1/2002 to Q2/2012. Summary statistics for all variables are presented in Table 1 for the full sample and Table A2 in Appendix by period (2002-06, 2007-09 and 201012). The measures for REIT and mutual fund trading behavior, $B S I_{I N S T}$ and $B S I_{M F}$ respectively, suggest, on average, a net buying behavior for both type of investors over our sample period, with mutual funds showing a more pronounced net buyer attitude than institutions also invested in the unsecuritized market. The different average illiquidity measures (AMILLIQMARKET and 
AMILLIQ $Q_{\text {COM }}$ ) are similar if we exclude the one referring to individual REITs (AMILLI $Q_{\text {REIT }}$, where a higher value can be expected. On average $40 \%$ of the REITs in our sample are included in S\&P indexes, while the average institutional ownership is around $71 \%$. If we then turn to the risk/return factors of the asset pricing model, we find that REITs and the equity market have respectively performed on average $3.90 \%$ and $1.27 \%$ per quarter, while the three other factors of the Cahart (1997) model show positive factor loadings on average.

\section{[Insert Table 1 here]}

Panel A in Table 2 presents pairwise correlations between the sentiment, liquidity and return variables. Institutional investor sentiment in the commercial real estate market $\left(R E R C_{S E N T}\right)$ and their trading behavior in the REIT market $\left(B S I_{I N S T}\right)$ are significantly negatively correlated. To further assess the relationship between these two variables over time, we determine the pairwise correlations between $R E R C_{S E N T}$ and $B S I_{I N S T}$ for the pre-crisis, crisis and post-crisis period, which are presented in Panel B in Table 2. While the correlation coefficients are negative yet insignificant during the pre- and post-crisis, the two variables have a significantly negative correlation during the financial crisis (2007-2009). Thus, the more pessimistic institutional investors were about the private real estate market, the more did they behave like net buyers in the REIT market. Panel B suggests that the significantly negative correlation between the two variables in Panel A is primarily driven by the crisis period. Overall, the significantly negative correlation of $R E R C_{S E N T}$ and $B S I_{I N S T}$ in Table 2 provides initial evidence for the flight to liquidity theory, at least during the financial crisis. 
The relationship of $B S I_{I N S T}$ and $R E R C_{S E N T}$ over time is also graphically depicted in Figure 1, which clearly shows the significantly negative correlation between the two variables during the crisis years, particularly from the second quarter of 2007 to the fourth quarter of 2009. Interestingly, Figure 1 shows a noticeable drop in the $B S I_{I N S T}$ measure, i.e. a net selling behavior of institutional investors, between the second quarter of 2006 and the first quarter of 2007. This may be related to a number of factors such as the end of the housing boom, stock market conditions at this particular time or a preference of institutional investors for certain types of unsecuritized real estate such as multi-family housing over REIT stocks, as the institutional investor sentiment in the commercial real estate market $\left(R E R C_{S E N T}\right)$ was relatively high in this period.

\section{[Insert Figure 1 here]}

As shown in Panel A in Table 2, the trading behavior of institutional investors in the REIT market $\left(B S I_{I N S T}\right)$ is significantly positively correlated with the trading behavior of mutual funds $\left(B S I_{M F}\right)$, the illiquidity of a particular REIT (AMILLIQ $\left.Q_{R E I T}\right)$, the REIT market (AMILLIQ $\left.Q_{M A R K E T}\right)$ and the commercial real estate market $\left(A M I L L I Q_{C O M}\right)$. An increase in commercial real estate illiquidity increases the net buying behavior in the REIT market, which provides evidence for a fundamentals-driven flight to liquidity. Additionally, the increase in institutional trading if REIT market and individual REIT illiquidity are high appears to be in line with the findings of Devos et al. (2013) that institutional investors moved towards REITs with higher turnover (liquidity) during times of economic crisis.

\section{[Insert Table 2 here]}




\section{Methodology}

To investigate whether the flight to liquidity or style investing theory has the highest explanatory power for the effect of institutional real estate investor sentiment in the unsecuritized real estate market on REIT trading behavior, we first conduct diagnostic tests to identify unit roots and transform non-stationary variables to remove them. We then employ a linear regression model to our unbalanced panel dataset, and regress $B S I_{I N S T}$ on $R E R C$ sentiment, illiquidity and control variables as shown in Equation 3. In our linear regression, we control for firm-fixed effects.

$$
\begin{aligned}
& B S I_{\text {INST }_{i, t}}={ }_{i}+{ }_{1} R E R C_{S E N T}+{ }_{2} A M M I L I Q_{R E I T_{i, t}}+{ }_{3} A M I L L I Q_{M_{A R K E T}}+ \\
& { }_{4} A^{A M I L L I Q} \mathrm{COM}_{t}+{ }_{5} \mathrm{BSI}_{\mathrm{MF}_{i, t}}+{ }_{6} \text { INSTOWN }_{i, t}+{ }_{7} \operatorname{SPINDEX}_{i, t}+{ }_{8} \mathrm{X}+{ }_{i, t}
\end{aligned}
$$

Where $B S I_{I N S T}$ is the buy sell index for institutional investors in REITs in line with Kumar and Lee (2006), $i$ indexes firms and $t$ indexes time (in quarters), $\alpha_{\mathrm{i}}$ is the intercept, which controls for firm fixed effects, and $\varepsilon$ is the error term. $R E R C_{S E N T}$ is the institutional investor sentiment in the commercial real estate market. AMILLIQREIT, AMILLIQMARKET and AMILLIQCOM are the Amihud (2002) illiquidity measures for individual REITs, the REIT market and the commercial real estate market respectively. $B S I_{M F}$ is the buy sell index for mutual funds investing in REITs. INSTOWN is the percentage of institutional ownership in a REIT. SPINDEX is a binary variable coded 1 for quarters in which a REIT was included in an S\&P index. $X$ is a vector of economic and capital market control variables ( $S P R, T R M, U N P$ and $S N P)$.

Furthermore, to assess the impact of institutional real estate investor sentiment on REIT returns, we regress the quarterly REIT returns on $R E R C_{S E N T}$, the four systematic risk factors, the mean adjusted Amihud (2002) illiquidity measure and the lags of REIT returns and RERCSENT as shown in Equation 4. 


$$
\begin{aligned}
& \operatorname{RET}_{\text {REIT }}=+{ }_{1}{ }_{1} \mathrm{RERC_{ \text {SENT } }}+{ }_{2} \mathrm{MKT}+{ }_{3} \mathrm{SMB}+{ }_{4} \mathrm{HML}+{ }_{5} \mathrm{MOM}+ \\
& { }_{6} A M I L L I Q_{M A}+{ }_{7} \operatorname{lagRET} T_{R E I T}+{ }_{8} \operatorname{lagRER} C_{S E N T}+{ }_{i, t}
\end{aligned}
$$

Where $R E T_{R E I T}$ are quarterly REIT returns, $i$ indexes firms and $t$ indexes time (in quarters), $R E R C_{S E N T}$ is the institutional investor sentiment in the commercial real estate market, $M K T$, $S M B, H M L$ and $M O M$ are systematic risk factors in line with Fama and French (1993) and Carhart (1997). AMILLIQ $Q_{M A}$ is the mean adjusted Amihud (2002) illiquidity measure. $\operatorname{LagRET}_{R E I T}$ and lagRERC $C_{S E N T}$ are lags of the respective variables.

\section{Results}

\section{Institutional Investor Sentiment and Trading Behavior In Securitized Markets}

Table 3 presents the results for our analysis of the relationship of institutional real estate investor sentiment $\left(R E R C_{S E N T}\right)$ and REIT trading behavior $\left(B S I_{I N S T}\right)$. In our estimation using the full sample (Overall Sample column), the coefficient on $R E R C_{S E N T}$ is positive, yet insignificant. However, this initial aggregated analysis fails to distinguish between different investor habitats and time periods, which may explain the insignificant coefficient. To assess sentiment-induced institutional trading in the securitized real estate market further, we conduct the following disaggregated analyses.

\section{[Insert Table 3 here]}

Previous studies have shown that institutional investors prefer larger and older stocks (Devos et al., 2013; Below, Stansell and Coffin, 2000; Graff and Young, 1997), which can be considered the habitat of institutional investors. Clayton and MacKinnon (2003b) provide further support for an institutional investor habitat characterized by large cap REITs. Consequently, we investigate the relationship of $R E R C_{S E N T}$ and $B S I_{I N S T}$ for stocks that form the institutional and individual 
investor habitat. We define the institutional investor habitat as securities (i.e. REITs) included in S\&P indices (i.e. larger and older REITs) and REITs with high (above median) institutional ownership. On the other hand, securities in the individual investor habitat are characterized as stocks not included in S\&P indices (i.e. small and medium cap REITs) and with low (below median) institutional ownership. We then estimate our model as shown in Equation 3 for each of the different investor habitats.

The results of our analysis disaggregated by investor habitat are presented in Table 3. Except for securities with low institutional ownership, the coefficients on $R E R C_{S E N T}$ are insignificant for S\&P Index, non-S\&P index and high institutional ownership REITs. These initial results suggest that the irrational sentiment of institutional investors in the unsecuritized market has no effect on their trading behavior in the securitized market within the institutional habitat. The positive coefficient for stocks with low institutional ownership provides initial support for style investing. An increase in optimism (pessimism) about the commercial real estate market increased the buying (selling) behavior of institutional investors in low institutional ownership stocks. In other words institutional investors may have decided to increase the exposure to securitized assets with low institutional ownership to obtain more investment opportunities and pre-empt the action of individual investors to gain profits. However, we further disaggregate our analysis by time period and property type to assess the robustness of these results, and discuss them in the remainder of this paper.

The coefficients on the Amihud (2002) illiquidity measures of individual REITs $\left(A M I L L I Q_{R E I T}\right)$, overall public market $\left(A M I L L I Q_{M A R K E T}\right)$ and private market $\left(A M I L L I Q_{C O M}\right)$ are insignificant across all samples in Table 3. The trading behavior of mutual funds $\left(B S I_{M F}\right)$ has a positive relationship with that of institutional real estate investors $\left(B S I_{I N S T}\right)$. It is beyond the 
scope of this study to investigate how the trading behaviors of different types of institutional investors are related. However, one explanation for this consistently positive and significant relationship is herding among different institutional investors, i.e. mutual funds, pension funds, investment managers and insurance companies. The coefficients on the macro-economic variables such as credit risk spread $(S P R)$, term structure (TRM), unemployment $(U N P)$ and S\&P500 returns $(S N P)$ are consistent with expectations about their direction, but vary in significance.

Devos et al. (2013) show that the preferences of institutional REIT investors have changed over time, particularly around the most recent financial crisis. As a consequence, we estimate our model for the pre-crisis (2002-2006), financial crisis (2007-2009) and post-crisis (2010-2012) period. To identify the financial crisis period (2007 to 2009), we follow Devos et al. (2013).

\section{[Insert Table 4 here]}

Table 4 presents the results for the overall sample separated by time periods. In the pre-crisis years, the coefficient on $R E R C_{S E N T}$ is significantly positive at the $1 \%$ level, and this provides evidence for a style investing of institutional investors in the real estate category. If institutional investors were irrationally optimistic (pessimistic) about the underlying private market, they behaved like net buyers (sellers) in the securitized market. However, during the crisis period, the relationship between $R E R C_{S E N T}$ and $B S I_{I N S T}$ changed from positive to negative, as shown by the significantly negative coefficient on $R E R C_{S E N T}$. Thus, the more pessimistic institutional investors were about the unsecuritized market, the higher was the amount of securitized real estate assets they purchased, with this result supporting the flight to liquidity theory. In the post-crisis period from 2010 to 2012, institutional investor sentiment in the private market had a significantly 
negative effect on the institutional trading behavior in securitized markets (i.e. REITs). This result suggests a fundamental change in institutional preferences from the pre- to the post-crisis period due to the financial crisis, in line with Devos et al. (2013).

\section{[Insert Table 5 here]}

Next we contrast stocks forming the institutional investor habitat (included in the S\&P index) with those in the individual investor habitat (not included in the S\&P index) over different time

periods. Results are presented in Table 5. The significantly positive coefficients on $R E R C_{S E N T}$ for the period of 2002 to 2006 provide further support for a style investing of institutional investors in the real estate category, when markets were booming. Interestingly, the coefficient on $R E R C_{S E N T}$ is positive and significant at the $5 \%$ and $1 \%$ level respectively for S\&P and non-S\&P REITs. These findings for the pre-crisis period are in line with our previous findings for the overall sample in Table 4, suggesting that the style investing theory has the highest explanatory power for the sentiment-induced institutional trading behavior in the securitized market in this time period, irrespective of whether securities belong to the individual or institutional investor habitat.

For the financial crisis period of 2007 to 2009, instead, the coefficient on $R E R C_{S E N T}$ again changes direction and becomes significantly negative at the $1 \%$ for S\&P and non-S\&P REITs, which supports our previous findings for the full sample (Table 4). The more pessimistic institutional investors were about the unsecuritized real estate market, the more they behaved as net buyers in the securitized real estate market. These results suggest a sentiment-induced capital switching between the illiquid private and more liquid public real estate market, irrespective of habitat, in line with the flight to liquidity theory. Our results mirror the ones of Devos et al. 
(2013), who show that some institutional investors such as banks significantly increased their REIT ownership during the financial crisis.

For the post-crisis period of 2010 to 2012, the coefficient on $R E R C_{S E N T}$ is negative yet insignificant for stocks included in the S\&P500 index and significantly negative at the 5\% level for non-S\&P500 stocks. The financial crisis has hence changed the relationship of $R E R C_{S E N T}$ and $B S I_{I N S T}$ from positive (category theory) to negative (flight to liquidity), probably due to a higher risk perception of investors with regard to unsecuritized real estate markets despite the mild recovery subsequent to the financial crisis. Our results are in line with previous findings of Devos et al. (2013) that the investment behavior and preferences of institutional REIT investors changed with economic conditions. Devos et al. (2013) find that institutional investors placed a greater emphasis on managing risk following the crisis. In particular, the authors show that insurance companies and banks have become more conservative after the crisis. Our findings suggest that this emphasis on lower risk exposure also holds for the relationship of unsecuritized and securitized market investments, and led institutional investors to switch capital between these two markets based on perceived risk levels in the crisis and post-crisis period.

The results of our time-period specific analysis for the full sample in Table 4 as well as S\&P and non-S\&P REITs in Table 5 indicate that the initial aggregated analysis in Table 3 masks differences in the relationship of $R E R C_{S E N T}$ and $B S I_{I N S T}$ over time. The insignificant coefficients on $R E R C_{S E N T}$ for S\&P, non-S\&P and high institutional ownership REITs in Table 3 are likely the result of directional changes in the investigated relationship over time, due to style investing in positive economic conditions (2002 to 2006) and a flight to liquidity in difficult economic environments (2007 to 2009). 
To assess the robustness of our findings, we conduct two robustness checks. First, we estimate our model as shown in Equation 3 for portfolios of REITs with above median (high) and below median (low) institutional ownership, which represents an alternative proxy for the habitat of institutional and individual investors. Our results are presented in Table 6. The coefficients on $R E R C_{S E N T}$ for both types of REITs are significantly positive in the pre-crisis period (2002 to 2006), significantly negative in the crisis period (2007 to 2009) and negative, but insignificant in the post-crisis period (2010 to 2012). These results suggest that our main findings are robust to different definitions of individual and institutional investor habitat. Institutional investors style invested in the pre-crisis period and showed a flight to liquidity in the crisis period and to a lesser extent in the post-crisis period.

\section{[Insert Table 6 here]}

As a second robustness check, we estimate our model for different property types in all three periods. As shown in Table 7, the coefficients on $R E R C_{S E N T}$ are consistent across asset types, although varying in significance. In particular, coefficients are significantly positive in the precrisis period for industrial, retail and hotel REITs, but insignificant for office REITs. Interestingly, the coefficient on $R E R C_{S E N T}$ for multi-family REITs is significantly negative in the pre-crisis period. During the crisis period, institutional investor sentiment in the private market is significantly negatively related to institutional trading of REITs of all property type specializations, except hotel. While the coefficient for hotel REITs is in the expected direction, the insignificance may stem from low statistical power due to a relatively small sample size. Last, while the coefficients on $R E R C_{S E N T}$ for all property type specializations in the post-crisis period are negative, only the one for hotel REITs is significant. Overall, the results for different property types support our previous findings. The applicability of style investing and flight to 
liquidity theory depends on economic conditions: in pre-crisis conditions style investing best explains sentiment-induced institutional trading behavior in the securitized real market, while in crisis and to some extent in the post-crisis conditions the flight to liquidity theory is more suitable.

\section{[Insert Table 7 here]}

\section{Institutional Investor Sentiment and Securitized Asset Pricing}

Table 8 presents the results for the effect of institutional investor sentiment in the unsecuritized market on asset pricing in the securitized market. For the overall sample, institutional investor sentiment in the commercial real estate market has a significantly positive effect on REIT returns. For the pre-crisis period of 2002 to $2006, R E R C_{S E N T}$ also has a significantly positive effect on the returns of REITs in the individual and institutional investor habitat. This is in line with the significantly positive correlation between institutional investor sentiment in the private real estate market and REIT returns identified by Ling, Naranjo and Scheick (2013). The sentiment-induced trading behavior of institutional investors in the securitized real estate market identified previously introduces additional systematic risk into asset pricing in line with previous studies (Barberis, Shleifer and Wurgler, 2005; Barberis and Shleifer, 2003). While the effect of institutional investor sentiment on the returns of large cap REITs (institutional investor habitat) is in line with earlier studies (Clayton and MacKinnon, 2003b; Graff and Young, 1997), we also find an impact on the returns of REITs in the individual investor habitat. This effect can be explained with the presence of fewer fundamental traders and greater limits to arbitrage in this habitat. An additional explanation for the impact of institutional sentiment on the return of REITs in the individual investor habitat is that institutional trading signals information to less 
informed individual investors. Lee, Lee and Chiang (2008) argue that individual investors use institutional investors as a source of information, and follow them in and out of small cap REITs based on private market performance. As individual investors are less likely to be able to determine whether institutional trading is based on private market fundamentals (e.g. performance) or irrational sentiment, they also likely follow institutional investors in and out of REITs in their habitat based on sentiment.

\section{[Insert Table 8 here]}

In the crisis (2007 to 2009), RERC $C_{S E N T}$ has a positive yet insignificant coefficient for the S\&P REIT sample and a significantly positive coefficient for non-S\&P REITs. The insignificant coefficient for the crisis period is puzzling. One explanation for the non-existing effect of commercial investor sentiment on the pricing of S\&P REITs between 2007 and 2009 may be that factors such as the flight to quality (Devos et al., 2013) have increased the presence of fundamentals traders in these larger, older and relatively more liquid stocks. These investors in turn may face lower limits to arbitrage in these REITs and be able to arbitrage away the additional sentiment-induced risk. On the other hand, arbitrage may be too costly in REITs forming the habitat of individual investors (Kumar and Lee, 2006), and this explains the persistent effect of private market sentiment on securitized returns.

The significantly positive coefficient on $R E R C_{S E N T}$ for non-S\&P REITs is also somewhat counter-intuitive. With regards to our previous findings for $B S I_{I N S T}$, if institutional investors as a group are pessimistic about the private market during the financial crisis, and switch their investments from private to public real estate, we expect a negative coefficient. This aggregated trading behavior (flight to liquidity) should increase the systematic risk in REITs, when 
institutional investors are pessimistic, and consequently increase returns to compensate for this additional risk.

Commercial real estate sentiment has a significantly positive effect on institutional trading behavior for S\&P REITs, but no effect for non-S\&P REITs in the post-crisis period. Analogously to the crisis period, these effects are somewhat counter-intuitive, particularly with regard to our findings for $B S I_{I N S T}$ in Table 5. Overall, our results for the crisis and post-crisis period suggest that further investigations into the relationship of commercial real estate sentiment and REIT returns, particularly across different investor habitats and for these time periods, are needed.

\section{Conclusion}

Our study yields a number of interesting results. First, we show that the sentiment of institutional investors in the underlying unsecuritized real estate market affects their trading behavior in the securitized market, suggesting a spillover effect of irrational sentiment between private and public market. Moreover, our findings suggest that the direction of sentiment-induced trading behavior of institutional investors in the securitized market depends on economic conditions, particularly with regard to the most recent financial crisis (2007 to 2009).

During times of favorable economic and property market conditions such as 2002 to 2006 (pre-crisis), institutions style invested in the real estate category based on their sentiment about the underlying private market. If institutional investors as a group felt irrationally optimistic (pessimistic) about commercial real estate, they would have increased (decreased) their investment in the real estate category, including both securitized and unsecuritized assets. Our study complements the extensive literature on style (category) investing theory (Choi and Sias, 
2009; Froot and Teo, 2008; Barberis, Shleifer and Wurgler, 2005; Barberis and Shleifer, 2003) by providing empirical evidence that institutional investors not only style-invest within the stock market, but also across asset markets (e.g. the unsecuritized and securitized real estate market). Our findings also contribute to the institutional herding literature (Sias 2004; Nofsinger and Sias, 1999) by showing that institutional investors as a group herd in and out of asset categories, increasing volatility and introducing a non-fundamental component into asset pricing. This is in line with the institutional herding effects found in Clayton and MacKinnon (2003b) and Graff and Young (1997).

Our finding that institutions style-invest in the real estate category based on sentiment represents a behavioral explanation for the comovement of securitized and unsecuritized real estate returns (Pagliari et al., 2005; Myer and Webb, 1993; Giliberto, 1990). Lee, Lee and Chiang (2008) find that sentiment linked to private markets has a high explanatory power for large cap securities (i.e. REITs) for the period of 1993 to 2003. The authors explain this finding with an increased involvement of institutions invested in both markets that strengthen the link between private market fundamentals and public asset returns. Our findings for the pre-crisis period support Lee, Lee and Chiang (2008).

For the crisis period, we find evidence of sentiment-induced capital switching between the illiquid unsecuritized real estate market and the more liquid securitized one. As institutional investors are highly sensitive to the illiquidity risk in commercial real estate (Dhar and Goetzmann, 2006), and have a preference for more liquid real estate investments such as REITs (Ciochetti, Craft and Shilling, 2002), we control for private and public market illiquidity to ensure that our results are not driven by fundamental illiquidity risk. Thus, our sentiment measure $\left(R E R C_{S E N T}\right)$ captures perceived (sentiment-based) risk in the private real estate market, 
as opposed to fundamentals-based liquidity risk. Our findings for the crisis period complement previous findings by Devos et al. (2013). While the earlier study showed a flight to quality of institutional investors within the REIT market, our study finds a flight to liquidity of institutional investors between the unsecuritized and securitized real estate market. Furthermore, we provide a behavioral explanation for the capital switching between real estate markets as discussed by Lee, Lee and Chiang (2008). In addition, our study also contributes to the flight to liquidity / quality literature (e.g. Baker and Wurgler, 2012; Brunnermeier and Pederson, 2009; Goyenko and Ukhov, 2009; Connolly, Stivers and Sun, 2007; Archarya and Pederson, 2005) by showing that a flight to liquidity not only occurs within the stock market or between bond \& stock market, but also between unsecuritized and securitized markets of the same asset (e.g. direct investment in real estate and REITs).

Overall, our findings suggest that the style investing and flight to liquidity theory are complementary rather than substitute theories for the sentiment-induced trading behavior of institutional investors in the REIT market. Our results hold across different groups of securities (e.g. REITs with high and low institutional ownership, included or not in the S\&P index) and property types. Our study provides additional evidence that the financial crisis has changed the preferences of institutional investors towards financial assets that imply a lower risk exposure (Devos et al. 2013). Future studies with larger post-crisis datasets may investigate whether this effect is temporary or persistent, as well as implications for institutional portfolio performance.

Last, our investigation into the effect of institutional investor sentiment on securitized real estate pricing suggests that not only the sentiment of individual investors positively affects REIT returns (Lin et al., 2009; Chiang and Lee, 2009; Clayton and MacKinnon, 2003a; Barkham and Ward, 1999), but also institutional investor sentiment in the underlying private market. 
Our results have implications for future studies on investor sentiment in general and institutional investors in particular. First, institutional investors cannot be assumed to be rational, and future studies on investor sentiment in securitized or unsecuritized real estate markets need to account for both institutional and individual investor sentiment. Additionally, our findings suggest that investor sentiment studies should be time variant, and distinguish between different time periods as risk perception and investment behavior change over time. We consider our study a starting point for future investigations into institutional investor sentiment, the sentiment-driven trading behavior of institutional investors between private and public market as well as the effect of liquidity on investor sentiment. 


\section{Acknowledgements}

The authors would like to thank Seow Eng Ong, David Geltner, Piet Eichholtz, Andy Naranjo, David Downs, the participants of the 2013 Maastricht University-National University of Singapore-MIT (MNM) symposium and 2013 National AREUEA conference for their valuable comments. We also thank the Real Estate Research Corporation (RERC) for providing us with their data. 


\section{References}

Acharya, V. V., \& Pedersen, L. H. (2005). Asset Pricing with Liquidity Risk. Journal of Financial Economics, 77:375-410.

Ambrose, B. W., Lee, D. W., \& Peek, J. (2007). Comovement After Joining an Index: Spillovers of Nonfundamental Effects. Real Estate Economics, 35(1), 57-90.

Amihud, Y. (2002). Illiquidity and Stock Returns: Cross-Section and Time-Series Effects. Journal of Financial Markets, 5:31-56.

Amihud, Y., Mendelson, H., \& Wood, R. A. (1990). Liquidity and the 1987 stock market crash. Journal of Portfolio Management, 16(3), 65-69.

Amihud, Y., \& Mendelson, H. (1986). Asset Pricing and the Bid-Ask Spread. Journal of Financial Economics, 17:223-249.

Anand, A., Chakravarty, S., \& Martell, T. (2005). Empirical Evidence on the Evolution of Liquidity: Choice of Market versus Limit Orders by Informed and Uninformed Traders. Journal of Financial Markets, 8:289-309.

Badrinath, S. G., \& Wahal, S. (2002). Momentum Trading by Institutions. Journal of Finance, 57(6), 2449-2478.

Baker, M., \& Wurgler, J. (2012). Comovement and Predictability Relationships Between Bonds and the Cross-Section of Stocks. Review of Asset Pricing Studies, 2(1), 57-87.

Baker, M., \& Wurgler, J. (2007). Investor Sentiment in the Stock Market. Journal of Economic Perspectives, 21(2), 129-151.

Baker, M., \& Wurgler, J. (2006). Investor Sentiment and the Cross-Section of Stock Returns. Journal of Finance, 61(4), 1645-1680.

Baker, M., \& Stein, J. C. (2004). Market Liquidity as a Sentiment Indicator. Journal of Financial Markets, 7:271-299.

Barberis, N., Shleifer, A., \& Wurgler, J. (2005). Comovement. Journal of Financial Economics, 75:283-317.

Barberis, N., \& Shleifer, A. (2003). Style investing. Journal of Financial Economics, 68:161199. 
Barkham, R. J., \& Ward, C. W. R. (1999). Investor Sentiment and Noise Traders: Discount to Net Asset Value in Listed Property Companies in the U.K. Journal of Real Estate Research, $18(2), 291-312$.

Beber, A., Brandt, M. W., \& Kavajecz, K. A. (2009). Flight-to-Quality or Flight-to-Liquidity? Evidence from the Euro-Area Bond Market. Review of Financial Studies, 22(3), 925-957.

Below, S. D., Stansell, S. R., \& Coffin, M. (2000). The Determinants of REIT Institutional Ownership: Tests of the CAPM. Journal of Real Estate Finance and Economics, 21(3), 263-278.

Bianchi, D., \& Guidolin, M. (2014). Can Linear Predictability Models Time Bull and Bear Real Estate Markets? Out-of-Sample Evidence from REIT Portfolios. Journal of Real Estate Finance and Economics, 49(1), 116-164.

Brooks, C., \& Tsolacos, S. (1999). The Impact of Economic and Financial Factors on UK Property Performance. Journal of Property Research, 16(2), 139-152.

Brown, G. W., \& Cliff, M. T. (2004). Investor Sentiment and Asset Valuation. Journal of Business, 78(2), 405-440.

Brunnermeier, M. K., \& Pedersen, L. H. (2009). Market Liquidity and Funding Liquidity. The Review of Financial Studies, 22(6), 2201-2238.

Carhart, M. M. (1997). On Persistence in Mutual Fund Performance. Journal of Finance, 52:57 82.

Chen, H.-L., \& Bondt, W. D. (2004). Style Momentum Within the S\&P-500 Index. Journal of Empirical Finance, 22:483-507.

Chen, N.-F., Kan, R., \& Miller, M. H. (1993). Are the Discounts on Closed-End Funds a Sentiment Index?. Journal of Finance, 48(2), 795-800.

Chiang, K. C. H., \& Lee, M.-L. (2009). The Role of Correlated Trading in Setting REIT Prices. Journal of Real Estate Finance and Economics, 41:320-338.

Choi, N., \& Sias, R. W. (2009). Institutional Industry Herding. Journal of Financial Economics, 94: 469-491.

Ciochetti, B. A., Craft, T. M., \& Shilling, J. D. (2002). Institutional Investors' Preferences for REIT Stocks. Real Estate Economics, 30(4), 567-593.

Clayton, J., Ling, D. C., \& Naranjo, A. (2009). Commercial Real Estate Valuation: Fundamentals Versus Investor Sentiment. Journal of Real Estate Finance and Economics, 38:537. 
Clayton, J., \& MacKinnon, G. (2003a). Departures from NAV in REIT Pricing: The Private Real Estate Cycle, the Value of Liquidity and Investor Sentiment, RERI Working Paper, No. 106.

Clayton, J., \& MacKinnon, G. (2003b). The Relative Importance of Stock, Bond and Real Estate Factors in Explaining REIT Returns. Journal of Real Estate Finance and Economics, 27(1), 3960.

Connolly, R. A., Stivers, C., \& Sun, L. (2007). Commonality in the Time-Variation of StockStock and Stock-Bond Return Comovements. Journal of Financial Markets, 10:192-218.

De Long, J. B., \& Shleifer, A. (1992). Closed-end Fund Discounts. Journal of Portfolio Management, 18(2), 46-53.

De Long, J. B., Shleifer, A., Summers, L. H., \& Waldmann, R. J. (1990). Noise Trader Risk in Financial Markets. Journal of Political Economy, 98(4), 703-738.

De Long, J. B., Shleifer, A., Summers, L. H., \& Waldmann, R. J. (1989). The Size and Incidence of the Losses from Noise Trading. Journal of Finance, 44(3), 681-696.

Devos, E., Ong, S.-E., Spieler, A. C., \& Tsang, D. (2013). REIT Institutional Ownership Dynamics and the Financial Crisis. Journal of Real Estate Finance and Economics, 47:266-288.

Dhar, R., \& Goetzmann, W. N. (2006). Institutional Perspectives on Real Estate Investing. Journal of Portfolio Management, 32(4), 106-116.

Doukas, J. A., \& Milonas, N. T. (2004). Investor Sentiment and the Closed-end Fund Puzzle: Out-of-sample Evidence. European Financial Management, 10(2), 235-266.

Elton, E. J., Gruber, M. J., \& Busse, J. A. (1998). Do Investors Care about Sentiment?. Journal of Business, 71(4), 477-500.

Fama, E. F., \& French, K. R. (1993). Common Risk Factors in the Returns on Stocks and Bonds. Journal of Financial Economics, 33: 3-56.

Fei, P. D., Ding, L., \& Deng, Y. (2010). Correlation and Volatility Dynamics in REIT Returns: Performance and Portfolio Considerations. Journal of Portfolio Management, 36(2), 113-125.

Froot, K., \& Teo, M. (2008). Style Investing and Institutional Investors. Journal of Financial and Quantitative Analysis, 43(4), 883-906.

Froot, K. A., \& Dabora, E. M. (1999). How are stock prices affected by the location of trade?. Journal of Financial Economics, 53:189-216 
Gallimore, P., \& Gray, A. (2002). The role of investor sentiment in property investment decisions. Journal of Property Research, 19(2), 111-120.

Gemmill, G., \& Thomas, D. C. (2002). Noise Trading, Costly Arbitrage, and Asset Prices: Evidence from Closed-end Funds. Journal of Finance, 57(6), 2571-2594.

Giliberto, S. M. (1990). Equity Real Estate Investment Trusts and Real Estate Returns. Journal of Real Estate Research, 5(2), 259-263.

Glushkov, D., Moussawi, R., \& Palacios, L. (2009). Institutional Ownership, Concentration, and Breadth Ratios Using Thomson Reuters 13F Data. WRDS Paper.

Goyenko, R. Y., \& Ukhov, A. D. (2009). Stock and Bond Market Liquidity: A Long-Run Empirical Analysis. Journal of Financial and Quantitative Analysis, 44(1), 189-212.

Graff, R. A., \& Young, M. S. (1997). Serial Persistence in Equity REIT Returns. Journal of Real Estate Research, 14(3), 183-214.

Green, T. C., \& Hwang, B.-H. (2009). Price-Based Return Comovement. Journal of Financial Economics, 93:37-50.

Ilmanen, A. (2003). Stock-Bond Correlations. Journal of Fixed Income, 13(2), 55-66.

Knotek, E. (2007). How Useful is Okun's Law?. Federal Reserve Bank of Kansas City Economic Review, 73-103.

Kumar, A., \& Lee, C. M. C. (2006). Retail Investor Sentiment and Return Comovements. Journal of Finance, 66(5), 2451-2486.

Lee, M.-L., Lee, M.-T., \& Chiang, K. C. H. (2008). Real Estate Risk Exposure of Equity Real Estate Investment Trusts. Journal of Real Estate Finance and Economics, 36:165-181.

Lee, C. M. C., Shleifer, A., \& Thaler, R. H. (1991). Investor Sentiment and the Closed-End Fund Puzzle. Journal of Finance, 46(1), 75-109.

Lin, C. Y., Rahman, H., \& Yung, K. (2009). Investor Sentiment and REIT Returns. Journal of Real Estate Finance and Economics, 39:450-471.

Ling, D. C., Naranjo, A., \& Scheick, B. (2013). Investor Sentiment, Limits to Arbitrage, and Private Market Returns. Real Estate Economics, in press.

Liu, W. (2006). A Liquidity-Augmented Capital Asset Pricing Model. Journal of Financial Economics, 82:631-671. 
Myer, F. C. N., \& Webb, J. R. (1993). Return Properties of Equity REITs, Common Stocks and Commercial Real Estate: A Comparison. Journal of Real Estate Research, 8(1), 87-106.

Neal, R., \& Wheatley, S. M. (1998). Do Measures of Investor Sentiment Predict Returns?. Journal of Financial And Quantitative Analysis, 33(4), 523:547.

Nofsinger, J. R., \& Sias, R. W. (1999). Herding and Feedback Trading by Institutional and Individual Investors. Journal of Finance, 54(6), 2263-2295.

Pagliari, J. L. Jr, Scherer, K. A., \& Monopoli, R. T. (2005). Public Versus Private Real Estate Equities: A More Refined, Long-Term Comparison. Real Estate Economics, 33(1), 147-187.

Pástor, L., \& Stambaugh, R. F. (2003). Liquidity Risk and Expected Stock Returns. Journal of Political Economy, 111(3), 642-685.

Pindyck, R. S., \& Rotemberg, J. J. (1993). The Comovement of Stock Prices. Quarterly Journal of Economics, 108(4), 1073-1103.

Pindyck, R. S., \& Rotemberg, J. J. (1990). The Excess Co-Movement of Commodity Prices. Economic Journal, 100:1173-1189.

Ro, S., \& Gallimore, P. (2013). Real Estate Mutual Funds: Herding, Momentum-Trading and Performance. Real Estate Economics, 42(1), 190-222. .

Schiller, R. J. (1989). Comovements in Stock Prices and Comovements in Dividends. Journal of Finance, 44(3), 719-729.

Sias, R. W. (2004). Institutional Herding. Review of Financial Studies, 17(1), 165-206.

Sias, R. W., Starks, L. T., \& Tinic, S. M. (2001). Is Noise Trader Risk Priced?. Journal of Financial Research, 24(3), 311-329.

Teo, M., \& Woo, S.-J. (2004). Style Effects in the Cross-Section of Stock Returns. Journal of Financial Economics, 74:367-398.

Vayanos, D. (2004). Flight to Quality, Flight to Liquidity, And the Pricing of Risk. NBER working paper 10327.

Wahal, S., \& Yavuz, M. D. (2013). Style Investing, Comovement and Return Predictability. Journal of Financial Economics, 107:136-154.

Yu, J., \& Yuan, Y. (2011). Investor Sentiment and the Mean-Variance Relation. Journal of Financial Economics, 100(2), 367-381. 
Table 1: Descriptive Statistics

Panel A: Sentiment measures

\begin{tabular}{llllll} 
& Mean & Median & Std. Dev & Minimum & Maximum \\
\cline { 2 - 6 } RERC $_{\text {SENT }}$ & 1.19 & 0.62 & 3.15 & -6.57 & 7.5 \\
BSI INST $_{\text {BSI }_{\text {MF }}}^{0.16}$ & 0.23 & 0.46 & -1.00 & 1 \\
\hline
\end{tabular}

Panel B: Illiquidity and Liquidity Measures

\begin{tabular}{llllll}
\hline AMILLIQ & \\
AMILLIT & 0.10 & 0.03 & 0.29 & 0.00 & 5.05 \\
AMILLIQ & 0.02 & 0.01 & 0.01 & 0.00 & 0.07 \\
\hline
\end{tabular}

Panel C: Fundamentals

\begin{tabular}{llllrl}
\hline SPR & 4.52 & 5.08 & 1.81 & 1.29 & 7.85 \\
TRM & 2.02 & 2.41 & 1.19 & -0.41 & 3.44 \\
UNP & 6.65 & 5.83 & 1.92 & 4.43 & 9.93 \\
SNP & 0.30 & 0.55 & 2.94 & -7.88 & 4.91 \\
SPINDEX & 0.40 & 0.00 & 0.49 & 0.00 & 1.00 \\
INSTOWN & 71.22 & 77.71 & 22.38 & 0.09 & 100 \\
\hline
\end{tabular}

Panel D: REIT Returns and Systematic Risk Factors

\begin{tabular}{llllll}
\hline RET $_{\text {REIT }}$ & 3.90 & 4.95 & 18.46 & -145.84 & 203.17 \\
MKT & 1.27 & 1.55 & 9.02 & -22.28 & 16.55 \\
SMB & 1.21 & 0.74 & 4.04 & -6.03 & 12.01 \\
HML & 0.87 & 0.80 & 6.62 & -13.63 & 23.85 \\
MOM & 0.08 & 0.45 & 3.32 & -13.97 & 5.75 \\
\hline
\end{tabular}

Note: This table presents the descriptive statistics for a sample of 2,357 REIT quarters (68 REITs) over the period of Q1/2002 to Q2/2012. RERCSENT measures institutional investor sentiment in different typological commercial real estate markets and is based on the "investment conditions" item in the RERC survey over the period of Q1/2002 to Q2/2012. BSI $I_{I N S}$ is the buy sell index for institutional investors in individual REITs in line

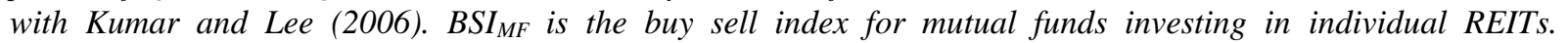
AMILLIQ $Q_{\text {REIT, AMILLIQ }}$ MARKET and AMILLIQ COM are the Amihud (2002) illiquidity measures for individual REITs, the REIT market and the commercial real estate market respectively. SPR is the default risk premium (spread) defined as difference between yield of BAA rated corporate bond and 1yr treasury bond. TRM is the term structure defined as difference between the yields of the 10-year treasury bond and 3-month treasury bill. UNP is the unemployment rate. SNP is the return on the S\&P500 index. SPINDEX is coded 1 for quarters in which a REIT is included in the S\&P 400, 500 or 600 index. INSTOWN is the percentage of institutional ownership in a REIT. RET REIT is the quarterly return for a particular REIT. MKT, SMB, HML and MOM are systematic risk factors. 


\section{Table 2: Correlations}

Panel A: Correlations of Sentiment Measures, Liquidity Measures and REIT Returns

\begin{tabular}{|c|c|c|c|c|c|c|c|}
\hline & RERC $_{\text {SENT }}$ & BSI INST $_{\text {INT }}$ & $\mathrm{BSI}_{\mathrm{MF}}$ & AMILLIQ REIT & AMILLIQMARKET & AMILLIQ $_{\mathrm{COM}}$ & RET $_{\text {REIT }}$ \\
\hline RERC $_{\text {SENT }}$ & 1 & & & & & & \\
\hline BSIINST & $-0.06 * * *$ & 1 & & & & & \\
\hline $\mathrm{BSI}_{\mathrm{MF}}$ & 0.01 & $0.15 * * *$ & 1 & & & & \\
\hline AMILLIQREIT & $-0.05 * *$ & $0.10 * * *$ & 0.02 & 1 & & & \\
\hline AMILLIQMARKET & $-0.12 * * *$ & $0.21 * * *$ & $0.08 * * *$ & $0.22 * * *$ & 1 & & \\
\hline AMILLIQ & $-0.21 * * *$ & $0.09 * * * *$ & $-0.07 * * *$ & $0.04 *$ & -0.03 & 1 & \\
\hline RET $_{\text {REIT }}$ & $0.08 * * *$ & $0.08 * * *$ & $0.05 * *$ & -0.01 & $-0.08 * * *$ & $0.19 * * *$ & 1 \\
\hline
\end{tabular}

Panel B: Correlations of Commercial Real Estate Investor Sentiment and REIT Trading Behavior Over Time

\begin{tabular}{lll}
\hline & & BSI INST \\
$\mathbf{2 0 0 2}$ - 2006 & RERC $_{\text {SENT }}$ & -0.03 \\
$\mathbf{2 0 0 7}-\mathbf{2 0 0 9}$ & RERC $_{\text {SENT }}$ & $\mathbf{- 0 . 2 4} * * *$ \\
$\mathbf{2 0 1 0}-\mathbf{2 0 1 2}$ & RERC $_{\text {SENT }}$ & -0.04 \\
\hline
\end{tabular}

Note: RERCSENT measures institutional investor sentiment in different typological commercial real estate markets and is based on the "investment conditions" item in the RERC survey over the period of Q1/2002 to Q2/2012. BSI INST is the buy sell index for institutional investors in individual REITs in line with Kumar and Lee (2006). BSI $I_{M F}$ is the buy sell index for mutual funds investing in individual REITs. AMILLIQ $Q_{R E I T}$, AMILLIQ $Q_{M A R K E T}$ and AMILLIQ ${ }_{\text {COM }}$ are the Amihud (2002) illiquidity measures for individual REITs, the REIT market and the commercial real estate market respectively. RET $T_{\text {REIT }}$ is the quarterly return for a particular REIT.

'***', '**' and '*' indicate significance at the 1\%, 5\% and $10 \%$ level respectively. 
Table 3: Results for Institutional Investor Trading Behavior in REITs (BSIINST)

\begin{tabular}{|c|c|c|c|c|c|}
\hline & \multirow{2}{*}{$\begin{array}{l}\text { Overall } \\
\text { Sample }\end{array}$} & \multirow{2}{*}{$\begin{array}{l}\text { S\&P } \\
\text { Index }\end{array}$} & \multirow{2}{*}{$\begin{array}{l}\text { Non-S\&P } \\
\text { Index }\end{array}$} & \multicolumn{2}{|c|}{ Institutional Ownership } \\
\hline & & & & High & Low \\
\hline RERC $_{\text {SENT }}$ & 0.01 & 0.00 & 0.00 & -0.01 & $0.02 *$ \\
\hline AMILLIQREIT & 0.01 & -0.09 & 0.01 & -0.07 & 0.01 \\
\hline AMILLIQMARKET & -0.20 & 1.96 & -0.53 & 0.48 & 0.04 \\
\hline AMILLIQ & 0.68 & 1.20 & 0.67 & 1.29 & 0.06 \\
\hline $\mathrm{BSI}_{\mathrm{MF}}$ & $0.14 * * *$ & $0.12 * * *$ & $0.13 * * *$ & $0.13 * * *$ & $0.12 * * *$ \\
\hline INSTOWN & $0.00 *$ & $0.01 * * *$ & 0.00 & $0.00 * * *$ & $0.00 * *$ \\
\hline SPINDEX & 0.02 & & & 0.03 & 0.01 \\
\hline SPR & -0.03 & $-0.04 *$ & -0.04 & -0.03 & -0.03 \\
\hline TRM & $0.28 * * *$ & $0.28 * * *$ & $0.30 * * *$ & $0.29 * * *$ & $0.28 * * *$ \\
\hline UNP & $-\mathbf{0 . 0 3} * * *$ & $-0.02 *$ & $-0.03 * *$ & $-0.03 * *$ & -0.03 \\
\hline SNP & $0.01 * * *$ & 0.00 & $0.01 * * *$ & $0.01 *$ & $0.01 * *$ \\
\hline Constant & $\mathbf{- 0 . 2 9} * * *$ & $-0.62 * * *$ & $-0.21 * *$ & $-0.56 * * *$ & $-0.26 * *$ \\
\hline $\begin{array}{l}\text { Firm-fixed } \\
\text { effects }\end{array}$ & Yes & Yes & Yes & Yes & Yes \\
\hline$R^{2}$ & 0.31 & 0.29 & 0.31 & 0.33 & 0.23 \\
\hline$N(n)$ & 2357 (68) & $933(44)$ & $1424(64)$ & $1562(60)$ & $795(51)$ \\
\hline
\end{tabular}

Note: This table presents the results for the regression of BSI INST on the following variables using firm-fixed effects linear regression (unbalanced panels). Results are reported for the overall sample, REITs that are included in a $S \& P$ index $(S \& P)$ and those that are not (Non-S\&P), REITs with above median and below median institutional ownership. RERCSENT measures institutional investor sentiment in different typological commercial real estate markets and is based on the "investment conditions" item in the RERC survey over the period of Q1/2002 to Q2/2012. BSI INST is the buy sell index for institutional investors in individual REITs in line with Kumar and Lee (2006). BSI MF $_{\text {is }}$ the buy sell index for mutual funds investing in individual REITs. AMILLIQ $Q_{R E I T}$, AMILLIQ $Q_{M A R K E T}$ and AMILLIQ the commercial real estate market respectively. SPR is the default risk premium (spread) defined as difference between yield of BAA rated corporate bond and lyr treasury bond. TRM is the term structure defined as difference between the yields of the 10-year treasury bond and 3-month treasury bill. UNP is the unemployment rate. SNP is the return on the S\&P500 index. INSTOWN is the percentage of institutional ownership in a REIT. SPINDEX is a binary variable coded 1 for quarters in which a REIT was included in an $S \& P$ index. The reported $R^{2}$ is the overall $R^{2}$ resulting from the respective within and between $R^{2} s$.

'***', '**' and '*' denote significance at the 1\%, 5\% and $10 \%$ level respectively. 
Table 4: Results for Institutional Investor Trading Behavior in REITs (BSIINST) for the Overall Sample Separated by Time

\begin{tabular}{llll}
\hline & $\mathbf{2 0 0 2 - 2 0 0 6}$ & $\mathbf{2 0 0 7 - 2 0 0 9}$ & $\mathbf{2 0 1 0 - 2 0 1 2}$ \\
\hline RERCSENT & $\mathbf{0 . 0 8} * * *$ & $\mathbf{- 0 . 1 0 * * *}$ & $\mathbf{- 0 . 0 3 *}$ \\
AMILLIQREIT & -0.01 & -0.06 & 0.08 \\
AMILLIQMARKET & $\mathbf{3 . 5 1} * *$ & $\mathbf{4 . 4 0} * *$ & $\mathbf{1 2 . 5 0} * *$ \\
AMILLIQ & $\mathbf{1 3 . 8 6} * * *$ & 0.05 & -1.17 \\
BSIMF & $\mathbf{0 . 1 0} * * *$ & $\mathbf{0 . 1 9} * * *$ & $\mathbf{0 . 1 3} * * *$ \\
INSTOWN & -0.00 & $\mathbf{0 . 0 1} * * *$ & 0.00 \\
SPINDEX & -0.04 & 0.08 & 0.04 \\
SPR & $\mathbf{- 0 . 4 2} * * *$ & -0.01 & 0.01 \\
TRM & $\mathbf{0 . 2 2} * * *$ & $\mathbf{0 . 2 9} * * *$ & 0.11 \\
UNP & $\mathbf{1 . 4 4} * * *$ & $-\mathbf{0 . 1 8} * * *$ & 0.07 \\
SNP & $\mathbf{- 0 . 0 3 * * *}$ & $\mathbf{0 . 0 6} * * *$ & 0.00 \\
Constant & $\mathbf{- 6 . 6 0} * * *$ & -0.09 & -0.99 \\
\hline Firm-fixed effects & Yes & Yes & Yes \\
$R^{2}$ & 0.43 & 0.15 & 0.06 \\
$N(n)$ & $1112(63)$ & $638(63)$ & $607(68)$ \\
\hline
\end{tabular}

Note: This table presents the results for the regression of BSI INST on the following variables using firm-fixed effects linear regression (unbalanced panels). Results are reported for the overall sample for pre-crisis (2002-2006), crisis (2007-2009) and post-crisis (2010-2012) period. $R E R C_{S E N T}$ measures institutional investor sentiment in different typological commercial real estate markets and is based on the "investment conditions" item in the RERC survey over the period of Q1/2002 to Q2/2012. BSI INST is the buy sell index for institutional investors in individual REITs in line with Kumar and Lee (2006). BSI $I_{M F}$ is the buy sell index for mutual funds investing in individual REITs. AMILLIQ REIT, AMILLIQ ${ }_{M A R K E T}$ and AMILLIQCOM are the Amihud (2002) illiquidity measures for individual REITs, the REIT market and the commercial real estate market respectively. SPR is the default risk premium (spread) defined as difference between yield of BAA rated corporate bond and 1yr treasury bond. TRM is the term structure defined as difference between the yields of the 10-year treasury bond and 3-month treasury bill. UNP is the unemployment rate. SNP is the return on the S\&P500 index. INSTOWN is the percentage of institutional ownership in a REIT. SPINDEX is a binary variable coded 1 for quarters in which a $R E I T$ was included in an $S \& P$ index. The reported $R^{2}$ is the overall $R^{2}$ resulting from the respective within and between $R^{2}$ s.

'***', '**' and '*' denote significance at the $1 \%, 5 \%$ and $10 \%$ level respectively. 
Table 5: Results for BSIInST Separated for S\&P and Non-S\&P REITs and Time Period

\begin{tabular}{|c|c|c|c|c|c|c|}
\hline & \multicolumn{2}{|c|}{$2002-2006$} & \multicolumn{2}{|c|}{ 2007-2009 } & \multicolumn{2}{|c|}{ 2010-2012 } \\
\hline & $S \& P$ & Non-S\&P & $S \& P$ & Non-S\&P & $S \& P$ & Non-S\&P \\
\hline RERC $_{\text {SENT }}$ & $0.09 * *$ & $0.08 * * *$ & $-0.08 * * *$ & $-0.13 * * *$ & -0.03 & $-0.06 * *$ \\
\hline AMILLIQREIT & 0.32 & -0.00 & 0.03 & -0.02 & 0.32 & 0.00 \\
\hline AMILLIQMARKET & 2.54 & $3.69 * *$ & 2.68 & 5.37 & $19.11 * * *$ & -1.35 \\
\hline AMILLIQ & $12.12 *$ & $14.59 * * *$ & 0.89 & -0.52 & $-1.81 *$ & -0.74 \\
\hline $\mathrm{BSI}_{\mathrm{MF}}$ & 0.12 & $0.10 * *$ & 0.10 & $0.24 * * *$ & $0.14 * * *$ & $0.16 * * *$ \\
\hline INSTOWN & $-0.01 *$ & -0.00 & $0.02 * * *$ & 0.00 & $0.01 * * *$ & -0.00 \\
\hline SPR & $-0.48 * * *$ & $-0.39 * * *$ & 0.02 & -0.06 & -0.04 & -0.06 \\
\hline TRM & $0.26 * * *$ & $0.21 * * *$ & $0.20 * * *$ & $0.37 * * *$ & 0.13 & 0.16 \\
\hline UNP & $1.47 * * *$ & $1.41 * * *$ & $-0.13 * * *$ & $-0.22 * * *$ & $0.14 *$ & -0.03 \\
\hline SNP & -0.01 & $-0.03 * * *$ & $0.04 * * *$ & $0.07 * * *$ & -0.00 & 0.00 \\
\hline Constant & $-6.27 * * *$ & $-6.56 * * *$ & $-0.89 * *$ & 0.53 & $-1.87 *$ & 0.58 \\
\hline $\begin{array}{l}\text { Firm-fixed } \\
\text { effects }\end{array}$ & Yes & Yes & Yes & Yes & Yes & Yes \\
\hline$R^{2}$ & 0.43 & 0.40 & 0.13 & 0.18 & 0.07 & 0.03 \\
\hline$N(n)$ & $243(21)$ & 869 (59) & $328(35)$ & $310(41)$ & $362(44)$ & $245(30)$ \\
\hline
\end{tabular}

Note: This table presents the results for the regression of BSI INST on the following variables using fixed effects linear regression (unbalanced panels). Results are reported for REITs that are in an $S \& P$ index and those that are not for the pre-crisis (2002-2006), crisis (2007-2009) and post-crisis (2010-2012) period. RERCSENT measures institutional investor sentiment in different typological commercial real estate markets and is based on the "investment conditions" item in the RERC survey over the period of Q1/2002 to Q2/2012. BSIINST is the buy sell index for institutional investors in individual REITs in line with Kumar and Lee (2006). BSI $I_{M F}$ is the buy sell index for mutual funds investing in individual REITs. AMILLIQ $Q_{\text {REIT, AMILLIQ MARKET and AMILLIQ COM }}$ are the Amihud (2002) illiquidity measures for individual REITs, the REIT market and the commercial real estate market respectively. INSTOWN is the percentage of institutional ownership in a REIT. SPR is the default risk premium (spread) defined as difference between yield of BAA rated corporate bond and lyr treasury bond. TRM is the term structure defined as difference between the yields of the 10-year treasury bond and 3-month treasury bill. UNP is the unemployment rate. SNP is the return on the $S \& P 500$ index. The reported $R^{2}$ is the overall $R^{2}$ resulting from the respective within and between $R^{2} s$.

'***', '**' and '*' denote significance at the 1\%, 5\% and $10 \%$ level respectively. 
Table 6: Results for BSIInst Separated for High and Low Institutional Ownership REITs and Time Period

\begin{tabular}{|c|c|c|c|c|c|c|}
\hline & \multicolumn{2}{|c|}{ 2002-2006 } & \multicolumn{2}{|c|}{ 2007-2009 } & \multicolumn{2}{|c|}{ 2010-2012 } \\
\hline & High & Low & High & Low & High & Low \\
\hline RERC $_{\text {SENT }}$ & $0.08 * * *$ & $0.08 * * *$ & $-0.10 * * *$ & $-0.13 * * *$ & -0.03 & -0.02 \\
\hline AMILLIQREIT & 0.48 & -0.06 & -0.11 & 0.01 & -0.17 & 0.21 \\
\hline AMILLIQMARKET & 2.59 & $4.80 * *$ & 3.61 & 7.35* & $12.75 * *$ & -10.70 \\
\hline AMILLIQCOM & $17.70 * * *$ & $10.13 * *$ & 0.23 & 0.76 & -0.17 & -0.41 \\
\hline $\mathrm{BSI}_{\mathrm{MF}}$ & 0.08 & $0.11 * *$ & $0.16 * *$ & $0.21 *$ & $0.13 * * *$ & $0.14 *$ \\
\hline INSTOWN & 0.00 & 0.00 & $0.01 * * *$ & $0.03 * * *$ & $0.01 * * *$ & 0.00 \\
\hline SPINDEX & -0.02 & -0.07 & 0.10 & 0.16 & 0.06 & 0.17 \\
\hline SPR & $-0.48 * * *$ & $-0.31 * * *$ & 0.02 & -0.11 & -0.01 & -1.09 \\
\hline TRM & $0.23 * * *$ & $0.21 * * *$ & $0.25 * * *$ & $0.33 * * *$ & 0.11 & $0.83 *$ \\
\hline UNP & $1.66 * * *$ & $1.10 * * *$ & $-0.17 * * *$ & $-0.19 * * *$ & 0.11 & 0.01 \\
\hline SNP & $-\mathbf{0 . 0 3} * * *$ & $-0.02 * *$ & $0.06 * * *$ & $0.06 * * *$ & -0.00 & $0.03 * *$ \\
\hline Constant & $-7.81 * * *$ & $-5.38 * * *$ & -0.34 & $\mathbf{- 0 . 5 8} * * *$ & -1.92 & 4.03 \\
\hline $\begin{array}{l}\text { Firm-fixed } \\
\text { effects }\end{array}$ & Yes & Yes & Yes & Yes & Yes & Yes \\
\hline$R^{2}$ & 0.47 & 0.28 & 0.19 & 0.05 & 0.03 & 0.18 \\
\hline$N(n)$ & $620(49)$ & $492(45)$ & $463(54)$ & $175(24)$ & $479(60)$ & $128(29)$ \\
\hline
\end{tabular}

Note: This table presents the results for the regression of $B S I_{I N S T}$ on the following variables using fixed effects linear regression (unbalanced panels). Results are reported for REITs with above median and below median institutional ownership for the pre-crisis (2002-2006), crisis (2007-2009) and post-crisis (2010-2012) period. $R_{R E R} C_{S E N T}$ measures institutional investor sentiment in different typological commercial real estate markets and is based on the "investment conditions" item in the RERC survey over the period of Q1/2002 to Q2/2012. BSI INST is the buy sell index for institutional investors in individual REITs in line with Kumar and Lee (2006). BSI ${ }_{M F}$ is the buy sell index for mutual funds investing in individual REITs. AMILLIQ $Q_{\text {REIT, AMILLIQ }}$ MARKET and AMILLIQ COM are the Amihud (2002) illiquidity measures for individual REITs, the REIT market and the commercial real estate market respectively. SPR is the default risk premium (spread) defined as difference between yield of BAA rated corporate bond and 1yr treasury bond. TRM is the term structure defined as difference between the yields of the 10-year treasury bond and 3-month treasury bill. UNP is the unemployment rate. SNP is the return on the S\&P500 index. SPINDEX is a binary variable coded 1 for quarters in which a REIT was included in an S\&P index. INSTOWN is the percentage of institutional ownership in a REIT The reported $R^{2}$ is the overall $R^{2}$ resulting from the respective within and between $R^{2} s$.

'***', '**' and '*' denote significance at the 1\%, 5\% and $10 \%$ level respectively. 
Table 7: Results for BSIInst by Property Type and Time Period

\begin{tabular}{|c|c|c|c|c|c|c|c|c|c|c|c|c|c|c|c|}
\hline & \multicolumn{3}{|c|}{ Office } & \multicolumn{3}{|c|}{ Industrial } & \multicolumn{3}{|c|}{ Retail } & \multicolumn{3}{|c|}{ Residential } & \multicolumn{3}{|c|}{ Hotel } \\
\hline & $\begin{array}{l}2002- \\
2006 \\
\end{array}$ & $\begin{array}{l}2007- \\
2009 \\
\end{array}$ & $\begin{array}{l}2010- \\
2012 \\
\end{array}$ & $\begin{array}{l}2002- \\
2006 \\
\end{array}$ & $\begin{array}{l}2007- \\
2009 \\
\end{array}$ & $\begin{array}{l}2010- \\
2012 \\
\end{array}$ & $\begin{array}{l}2002- \\
2006 \\
\end{array}$ & $\begin{array}{l}2007- \\
2009 \\
\end{array}$ & $\begin{array}{l}2010- \\
2012 \\
\end{array}$ & $\begin{array}{l}2002- \\
2006 \\
\end{array}$ & $\begin{array}{l}2007- \\
2009 \\
\end{array}$ & $\begin{array}{l}2010- \\
2012 \\
\end{array}$ & $\begin{array}{l}2002- \\
2006 \\
\end{array}$ & $\begin{array}{l}2007- \\
2009 \\
\end{array}$ & $\begin{array}{l}2010- \\
2012 \\
\end{array}$ \\
\hline RERCSENT & 0.07 & $-0.42 * *$ & -0.03 & $0.43 * *$ & $-0.54 * *$ & -0.10 & $0.14 * * *$ & $\mathbf{- 0 . 3 5} * * *$ & -0.11 & $-0.10 * *$ & $-0.66 * * *$ & -0.00 & $0.40 * *$ & -0.05 & $-0.22 * *$ \\
\hline AMILLIQREIT & 0.97 & -0.02 & 0.50 & 1.86 & -0.67 & -0.41 & 0.00 & -0.01 & 0.19 & -0.17 & -0.41 & $3.81 * *$ & -0.06 & 0.10 & -0.69 \\
\hline AMILLIQMARKET & 2.69 & $12.36 *$ & 11.68 & -4.76 & 10.15 & 6.05 & $6.50 * *$ & 3.36 & $20.69^{*}$ & $5.85 *$ & 7.96 & -2.24 & 15.07 & 5.72 & $51.83 * *$ \\
\hline AMILLIQ & $23.99 * *$ & 0.07 & 2.73 & 6.92 & -6.94 & 1.21 & $16.65^{* * *}$ & 1.17 & 0.63 & $15.68 *$ & $-11.47 * *$ & 16.75 & 116.70 & 16.94 & -46.20 \\
\hline $\mathrm{BSI}_{\mathrm{MF}}$ & 0.04 & 0.16 & $0.15^{*}$ & 0.15 & 0.16 & 0.08 & $0.11 *$ & $0.18 * *$ & $0.14 * * *$ & 0.10 & $0.30 * *$ & $0.13 * *$ & 0.02 & 0.24 & 0.01 \\
\hline INSTOWN & -0.01 & 0.00 & 0.00 & -0.00 & 0.00 & 0.01 & -0.00 & $0.01 * * *$ & 0.00 & -0.00 & $0.03 * * *$ & $0.01 * *$ & -0.01 & 0.01 & 0.01 \\
\hline SPINDEX & 0.06 & 0.11 & $-0.44 *$ & -0.19 & & & -0.07 & 0.09 & 0.11 & -0.22 & -0.10 & 0.02 & & & \\
\hline SPR & $-0.42 * * *$ & -0.08 & 0.40 & -0.27 & 0.08 & 0.57 & $-0.38 * * *$ & -0.16 & 0.10 & $-0.57 * * *$ & 0.07 & $-2.16 * *$ & $-0.40 *$ & -0.14 & $3.35 *$ \\
\hline TRM & $0.23 * * *$ & 0.26 & -0.06 & 0.31 & 0.02 & -0.10 & $0.11 *$ & $0.35 * *$ & 0.18 & $\mathbf{0 . 3 7} * * *$ & 0.25 & $1.06 * *$ & 0.29 & 0.46 & -1.34 \\
\hline UNP & $1.43 * * *$ & $-0.24 * * *$ & -0.05 & $1.31 * *$ & $-0.34 * *$ & -0.16 & $1.51 * * *$ & $-0.25 * * *$ & -0.14 & $1.28 * * *$ & $-0.21 * * *$ & $0.41 * * *$ & $1.24 * *$ & -0.11 & $-0.61 *$ \\
\hline SNP & -0.02 & $0.08 * *$ & -0.00 & -0.00 & $0.13 * *$ & 0.00 & $-0.05 * * *$ & $0.08 * *$ & 0.01 & $-0.03 * *$ & $0.07 * * *$ & 0.01 & $-0.08 * *$ & 0.04 & -0.03 \\
\hline Constant & $-6.02 * * *$ & 0.47 & -1.27 & $-6.25 * *$ & 0.68 & -1.91 & $-7.15 * * *$ & -0.04 & 0.03 & $-4.79 * * *$ & $2.15^{*}$ & 4.39 & $-7.44 * *$ & -0.38 & -8.48 \\
\hline Firm-fixed effects & Yes & Yes & Yes & Yes & Yes & Yes & Yes & Yes & Yes & Yes & Yes & Yes & Yes & Yes & Yes \\
\hline$R^{2}$ & 0.53 & 0.46 & 0.12 & 0.15 & 0.47 & 0.22 & 0.54 & 0.24 & 0.13 & 0.49 & 0.08 & 0.23 & 0.63 & 0.33 & 0.11 \\
\hline$N(n)$ & $188(11)$ & $84(10)$ & $84(11)$ & $41(3)$ & $33(3)$ & $34(4)$ & $441(24)$ & $247(24)$ & $221(25)$ & $216(11)$ & $106(11)$ & $102(11)$ & $54(4)$ & $49(5)$ & $68(7)$ \\
\hline
\end{tabular}

Note: This table presents the results for the regression of BSI ${ }_{I N S T}$ on the following variables using fixed effects linear regression (unbalanced panels). Results are reported for different property types and three distinct time periods. RERC $C_{S E N T}$ measures institutional investor sentiment in different typological commercial real estate markets and is based on the "investment conditions" item in the RERC survey over the period of Q1/2002 to Q2/2012. BSIINST is the buy sell index for institutional investors in individual REITs in line with Kumar and Lee (2006). BSI $I_{M F}$ is the buy sell index for mutual funds investing in individual REITs. AMILLIQ REIT, AMILLIQMARKET and AMILLIQ COM are the Amihud (2002) illiquidity measures for individual REITs, the REIT market and the commercial real estate market respectively. SPINDEX is a binary variable coded 1 for quarters in which a REIT was included in an S\&P index. SPR is the default risk premium (spread) defined as difference between yield of BAA rated corporate bond and 1yr treasury bond. TRM is the term structure defined as difference between the yields of the 10-year treasury bond and 3-month treasury bill. UNP is the unemployment rate. SNP is the return on the S\&P500 index. INSTOWN is the percentage of institutional ownership in a REIT. The reported $R^{2}$ is the overall $R^{2}$ resulting from the respective within and between $R^{2} s$.

'***', '**' and '*' denote significance at the 1\%, 5\% and $10 \%$ level respectively. 
Table 8: Results for REIT Return Separated by S\&P and Non-S\&P REITs and Time Period

\begin{tabular}{|c|c|c|c|c|c|c|c|}
\hline & \multirow[b]{2}{*}{$\begin{array}{l}\text { Full } \\
\text { Sample }\end{array}$} & \multicolumn{2}{|c|}{ 2002-2006 } & \multicolumn{2}{|c|}{ 2007-2009 } & \multicolumn{2}{|c|}{ 2010-2012 } \\
\hline & & $S \& P$ & $\begin{array}{l}\text { Non- } \\
\text { S\&P }\end{array}$ & $S \& P$ & $\begin{array}{l}\text { Non- } \\
\text { S\&P }\end{array}$ & $S \& P$ & $\begin{array}{l}\text { Non- } \\
\text { S\&P }\end{array}$ \\
\hline RERC $_{\text {SENT }}$ & $3.62 * * *$ & $2.65 * * *$ & $3.22 * * *$ & 2.27 & $9.66 * *$ & $3.28 *$ & 0.03 \\
\hline MKT & $0.60 * * *$ & $0.28 *$ & $0.21 * * *$ & $0.97 * * *$ & $1.00 * * *$ & $0.62 * * *$ & $0.70 * * *$ \\
\hline SMB & $0.50 * * *$ & $0.71 * * *$ & $0.83 * * *$ & 0.69 & $1.93 * *$ & $3.17 * * *$ & $2.94 *$ \\
\hline HML & $1.11 * * *$ & 0.08 & $0.26 * *$ & $1.45 * * *$ & 0.95 & $-2.67 * * *$ & -1.52 \\
\hline MOM & $0.83 * * *$ & 0.54 & $0.60 * * *$ & $2.21 * *$ & 1.13 & -0.22 & 0.62 \\
\hline AMILLIQMA & 0.05 & $2.14 * * *$ & $0.11 * * *$ & $0.54 * *$ & 0.06 & -0.15 & 0.02 \\
\hline lagRET $T_{\text {REIT }}$ & $-0.06 * * *$ & $-0.30 * * *$ & $-0.27 * * *$ & $-0.13 * *$ & -0.05 & $-0.22 * * *$ & $-0.12 *$ \\
\hline lagRERC ${ }_{\text {SENT }}$ & $-4.06 * * *$ & -1.35 & $-1.97 * * *$ & $-4.53 *$ & $-7.42 * *$ & -0.45 & 1.88 \\
\hline Constant & $2.40 * * *$ & -1.02 & $1.79 * *$ & $3.97 * *$ & 5.32 & $-7.83 * *$ & -4.37 \\
\hline Fixed effects & Yes & Yes & Yes & Yes & Yes & Yes & Yes \\
\hline & 0.47 & 0.16 & 0.30 & 0.56 & 0.51 & 0.48 & 0.50 \\
\hline$N(n)$ & $1677(68)$ & $183(21)$ & $625(57)$ & $237(34)$ & $218(37)$ & $248(42)$ & $166(30)$ \\
\hline
\end{tabular}

Note: This table presents the results for the regression of REIT returns (RET REIT) on the following variables using firm-fixed effects linear regression (unbalanced panels). Results are reported for the full sample, REITs that are in an $S \& P$ index and those that are not for three distinct time periods. RERC SENT measures institutional investor sentiment in different typological commercial real estate markets and is based on the "investment conditions" item in the RERC survey over the period of Q1/2002 to Q2/2012. MKT, SMB, HML and MOM are the four systematic risk factors. AMILLIQ $Q_{M A}$ is the mean-adjusted Amihud (2002) illiquidity measure.

'***', '**' and '*' denote significance at the $1 \%, 5 \%$ and $10 \%$ level respectively. 
Figure 1: Correlation of Institutional Investor Sentiment in the Private Market (RERC SENT) and REIT Trading Behavior $\left(B S I_{I N S T}\right)$ Over Time

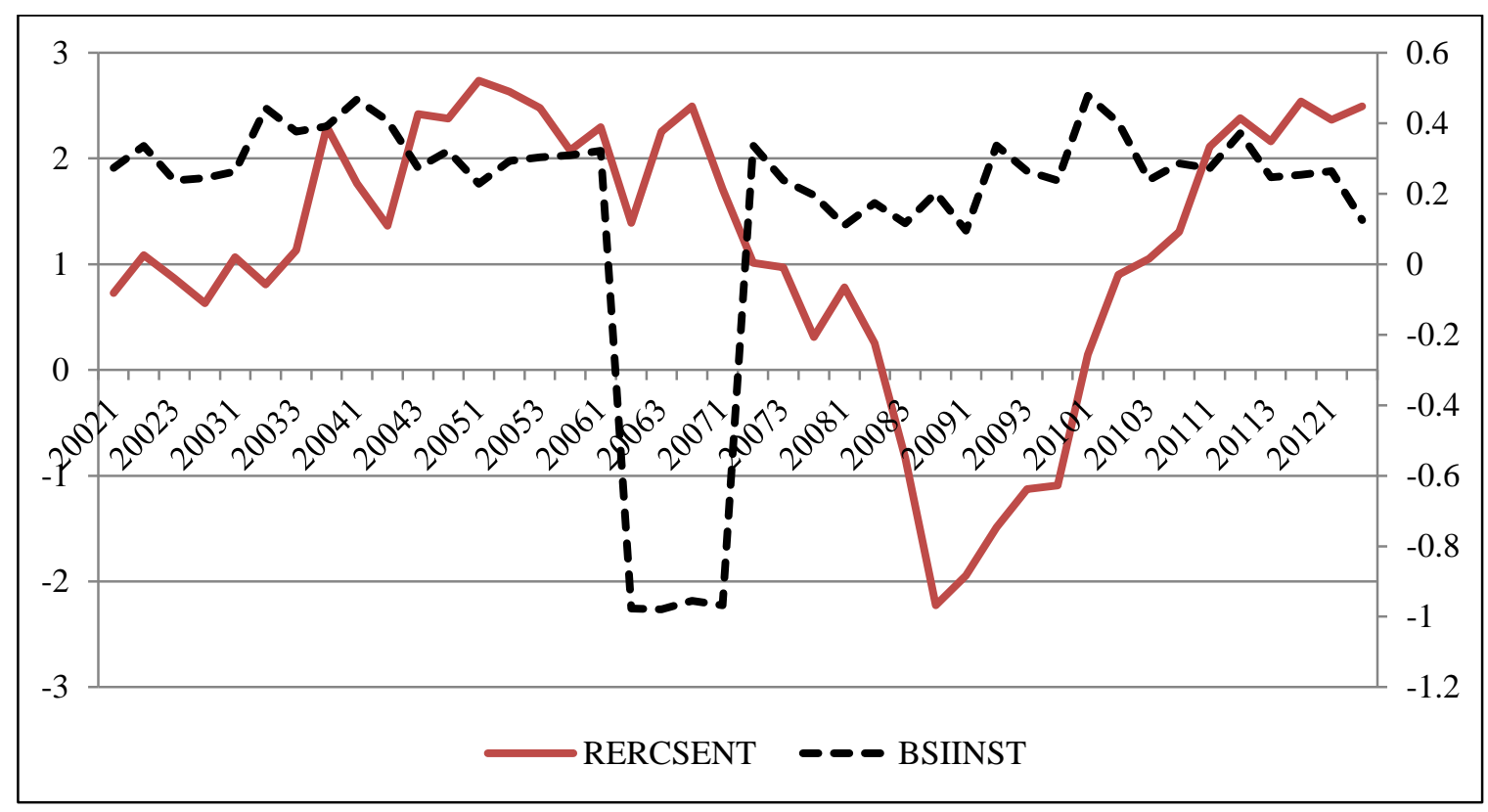

Note: This figure graphically presents the correlation between institutional investor sentiment in the commercial real estate market (RERC $\left.C_{S E N T}\right)$ and institutional trading behavior in REITs $\left(B_{S S I} I_{I N T}\right)$ over the period of Q1/2002 to Q2/2012. The $X$-axis measures time in year and quarter. The left $Y$-axis measures RERCSENT while the right $Y$-axis measures BSI INST. 


\section{Appendix}

Table A1: Data Description and Sources

\begin{tabular}{|c|c|c|c|}
\hline Variable & Definition & Derivation & Source \\
\hline RERCSENT & $\begin{array}{l}\text { Commercial real estate } \\
\text { market sentiment of } \\
\text { institutional investors }\end{array}$ & $\begin{array}{l}\text { "Investment conditions" in RERC survey; } \\
\text { principal common analysis used for property } \\
\text { types with more than one segment (office, } \\
\text { industrial, retail, diversified) to derive a score }\end{array}$ & $\begin{array}{l}\text { Quarterly survey of } \\
\text { institutional investors by Real } \\
\text { Estate Research Corporation } \\
\text { (RERC) }\end{array}$ \\
\hline BSIINST & $\begin{array}{l}\text { Buy sell index of } \\
\text { institutional investors; } \\
\text { BSI }_{\text {INST }}>0 \text { (net buyers); } \\
\text { BSI INST }_{\text {In }} \text { (net sellers) }\end{array}$ & $\begin{array}{l}\qquad B S I_{t}=\frac{\left(B_{t} S_{t}\right)}{\left(B_{t}+S_{t}\right)} \\
\text { Where } B_{t}\left(S_{t}\right) \text { is the quarterly long (short) } \\
\text { position of institutional investors in a particular } \\
\text { REIT. }\end{array}$ & $\begin{array}{l}\text { Institutional (13f) Holdings } \\
\text { database (s34) in Thomson } \\
\text { Reuters }\end{array}$ \\
\hline BSI MF & $\begin{array}{l}\text { Buy sell index of mutual } \\
\text { funds; } \mathrm{BSI}_{\mathrm{MF}}>0 \text { (net } \\
\text { buyers); } \mathrm{BSI}_{\mathrm{MF}}<0 \text { (net } \\
\text { sellers) }\end{array}$ & $\begin{array}{l}B S I_{t}=\frac{\left(B_{t} S_{t}\right)}{\left(B_{t}+S_{t}\right)} \\
\text { Where } B_{t}\left(S_{t}\right) \text { is the quarterly long (short) } \\
\text { position of mutual funds in a particular REIT. }\end{array}$ & $\begin{array}{l}\text { Mutual Fund Holdings } \\
\text { database (s12) in Thomson } \\
\text { Reuters }\end{array}$ \\
\hline AMILLIQREIT & $\begin{array}{l}\text { Amihud (2002) illiquidity } \\
\text { measure for an individual } \\
\text { REIT }\end{array}$ & $\begin{array}{l}I L L I Q_{i y}=\frac{\left|R_{i y}\right|}{V O L_{i y}} \\
\text { Where } R \text { is the absolute return and VOL the total } \\
\text { trading volume for a particular REIT. }\end{array}$ & CRSP \\
\hline AMILLIQMARKET & $\begin{array}{l}\text { Amihud (2002) illiquidity } \\
\text { measure for the REIT } \\
\text { market }\end{array}$ & $\begin{array}{l}\text { Quarterly value-weighted (by market } \\
\text { capitalization) aggregate of the REIT-level } \\
\text { illiquidity values. }\end{array}$ & CRSP \\
\hline AMILLIQсом & $\begin{array}{l}\text { Amihud (2002) illiquidity } \\
\text { measure for the } \\
\text { commercial real estate } \\
\text { market }\end{array}$ & $\begin{array}{l}I L L I Q_{i y}=\frac{\left|R_{i y}\right|}{V O L_{i y}} \\
\text { Where R is the absolute quarterly property-type } \\
\text { specific NCREIF transaction based index (NTBI) } \\
\text { total return and VOL is the dollar-denominated }\end{array}$ & NCREIF \\
\hline
\end{tabular}




\begin{tabular}{|c|c|c|c|}
\hline & & trading volume for a particular property type. & \\
\hline SPR & Default risk premium & $\begin{array}{l}\text { Difference between yields of BAA rated } \\
\text { corporate bond and } 1 \text { year treasury bond }\end{array}$ & $\begin{array}{l}\text { Federal reserve, } \\
\text { COMPUSTAT }\end{array}$ \\
\hline TRM & Term structure & $\begin{array}{l}\text { Difference between yields of } 10 \text { year T-bond and } \\
3 \text { month T-bill }\end{array}$ & Federal Reserve \\
\hline UNP & $\begin{array}{l}\text { Control for overall } \\
\text { economy }\end{array}$ & Unemployment rate (national) & Bureau of Labor Statistics \\
\hline SNP & $\begin{array}{l}\text { Control for general stock } \\
\text { market }\end{array}$ & Return on S\&P 500 composite index & CRSP \\
\hline SPINDEX & Inclusion in S\&P index & $\begin{array}{l}\text { Binary variable coded } 1 \text { for quarters in which an } \\
\text { individual REIT was included in the S\&P400, } \\
500 \text { or } 600 \text { index }\end{array}$ & NAREIT \\
\hline INSTOWN & $\begin{array}{l}\text { Institutional ownership in } \\
\text { an individual REIT }\end{array}$ & $\begin{array}{l}\text { Total institutional ownership as a percentage of } \\
\text { shares outstanding }\end{array}$ & Thomson Reuters \\
\hline RET $_{\text {REIT }}$ & Individual REIT returns & Quarterly returns for individual REITs & CRSP \\
\hline MKT & Market Risk Premium & See Fama French (1993) & $\begin{array}{l}\text { Fama French Factors } \\
\text { (WRDS) }\end{array}$ \\
\hline SMB & Small Minus Big factor & See Fama French (1993) & $\begin{array}{l}\text { Fama French Factors } \\
\text { (WRDS) }\end{array}$ \\
\hline HML & High Minus Low factor & See Fama French (1993) & $\begin{array}{l}\text { Fama French Factors } \\
\text { (WRDS) }\end{array}$ \\
\hline MOM & Momentum Factor & See Carhart (1997) & $\begin{array}{l}\text { Fama French Factors } \\
\text { (WRDS) }\end{array}$ \\
\hline
\end{tabular}


Table A2: Descriptive Statistics by Period

\begin{tabular}{lllllll}
\hline & Period & Mean & Median & Std. Dev & Minimum & Maximum \\
\hline RERCSENT & $2002-2006$ & 1.79 & 1.04 & 2.50 & -1.89 & 6.8 \\
& $2007-2009$ & -0.43 & -1.26 & 3.58 & -6.57 & 6.4 \\
& $2010-2012$ & 1.79 & 0.62 & 3.13 & -3.00 & 7.5 \\
\hline BSIINST & $2002-2006$ & 0.12 & 0.24 & 0.54 & -1.00 & 1.00 \\
& $2007-2009$ & 0.10 & 0.16 & 0.42 & -1.00 & 0.93 \\
& $2010-2012$ & 0.29 & 0.28 & 0.25 & -0.38 & 1.00 \\
\hline BSIMF & $2002-2006$ & 0.56 & 0.61 & 0.32 & -0.93 & 1.00 \\
& $2007-2009$ & 0.45 & 0.49 & 0.27 & -0.61 & 1.00 \\
\hline AMILLIQREIT & $2010-2012$ & 0.40 & 0.42 & 0.34 & -0.73 & 1.00 \\
& $2002-2006$ & 0.12 & 0.03 & 0.37 & 0.00 & 5.05 \\
& $2007-2009$ & 0.11 & 0.02 & 0.26 & 0.00 & 2.56 \\
\hline AMILLIQMARKET & $2010-2012$ & 0.06 & 0.01 & 0.11 & 0.00 & 0.94 \\
\hline AMILLIQCOM & $2007-2006$ & 0.02 & 0.02 & 0.02 & 0.01 & 0.07 \\
& $2010-2012$ & 0.02 & 0.02 & 0.01 & 0.00 & 0.05 \\
& $2002-2006$ & 0.00 & 0.00 & 0.01 & 0.00 & 0.03 \\
& $2007-2009$ & 0.01 & 0.00 & 0.02 & 0.00 & 0.10 \\
& $2010-2012$ & 0.01 & 0.00 & 0.02 & 0.00 & 0.08 \\
\hline SPINDEX & $2002-2006$ & 0.22 & 0 & 0.41 & 0 & 1 \\
& $2007-2009$ & 0.51 & 1 & 0.50 & 0 & 1 \\
\hline INSTOWN & $2010-2012$ & 0.60 & 1 & 0.49 & 0 & 1 \\
\hline RET REIT & $2002-2006$ & 64.79 & 71.27 & 24.53 & 0.09 & 100 \\
& $2007-2009$ & 76.43 & 81.25 & 18.17 & 20.51 & 100 \\
& $2010-2012$ & 77.50 & 82.47 & 18.79 & 8.39 & 100 \\
\hline & $2002-2006$ & 5.71 & 6.16 & 9.13 & -40.84 & 30.56 \\
& $2007-2009$ & -0.15 & -0.41 & 29.92 & -145.84 & 203.17 \\
& $2010-2012$ & 4.85 & 5.73 & 14.37 & -60.39 & 98.46 \\
\hline
\end{tabular}

Note: This table presents the descriptive statistics for our dataset for a sample of 2,357 REIT quarters (68 REITs) over the period of Q1/2002 to Q2/2012, separated by period. The period of 2002 to 2006 covers 1112 REIT quarters, 2007 to 2009 covers 638 REIT quarters and 2010 to 2012 covers 607 REIT quarters. RERC $C_{S E N T}$ measures institutional investor sentiment in the commercial real estate market and is based on the "investment conditions"

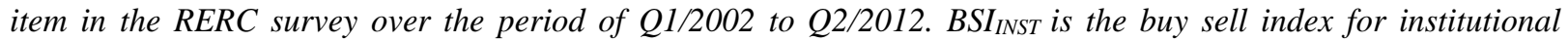
investors in individual REITs in line with Kumar and Lee (2006). BSI $I_{M F}$ is the buy sell index for mutual funds investing in individual REITs. AMILLIQ $Q_{\text {REIT, AMILLIQ }}$ MARKET and AMILLIQ ${ }_{\text {COM }}$ are the Amihud (2002) illiquidity measures for individual REITs, the REIT market and the commercial real estate market respectively. SPINDEX is coded 1 for quarters in which a REIT is included in the $S \& P 400,500$ or 600 index. INSTOWN is the percentage of institutional ownership in a REIT. RET REIT is the quarterly return for a particular REIT. 